\title{
Can Trade Work for the Environment?
}

\author{
The Promotion-Based Model
}

On September 19, 2000, the Committee on Trade and the Environment (CTE) issued a document entitled Matrix on Trade-Related Measures Pursuant to Selected Multilateral Environmental Agreements. ${ }^{1}$ The goal of the Matrix was to clarify which multilateral environmental treaties contained trade-related environmental measures, and to assess their relationship with the rules of the World Trade Organization (wTO) Agreements. Clarifying the relationship between trade-related provisions in multilateral environmental agreements (MEAs) and WTO rules was indeed part of the mandate of the Committee, stated first in the 1994 Decision on Trade and Environment and later confirmed in Doha. ${ }^{2}$ There are several reasons why MEA negotiators might decide to regulate trade or mandate the use of trade restrictions: for instance, to ensure the integrity of the regulatory framework created with the MEA itself, to artificially control the supply of a given product, when satisfying the demand to its fullest would deplete the resources on which it is based, or to prohibit trade in certain substances or products with non-parties to provide incentives both to join the agreement and to comply with its obligations. ${ }^{3}$ Indeed, environmental

1 WT/CTE/W/16o (Sept. 19, 2000) [hereinafter Matrix on Trade Measures Pursuant to Selected MEAs]. The document has been revised several times: WT/CTE/W/16o/Rev.1 (June 14, 2001), WT/CTE/W/16o/Rev.2 (Apr. 25, 2003), WT/CTE/W/16o/Rev.3 (Feb. 16, 2005), WT/CTE/W/16o/ Rev.4 (Mar. 14, 2007), WT/CTE/w/16o/Rev.5 (June 15, 2011), WT/CTE/W/16o/Rev.6 (Oct. 4, 2013), WT/CTE/W/16o/Rev. 7 (Sept. 4, 2015), WT/CTE/W/16o/Rev.6 (Oct. 9, 2017).

2 World Trade Organization, Ministerial Declaration of 14 November 2001, WT/MIN(o1)/DEC/ 1, 41 I.L.M. 746 (2002) [hereinafter Doha Declaration], para. 31(i).

3 An example of the third reason is offered by the Montreal Protocol which, developed under the framework of the Vienna Convention for the Protection of the Ozone Layer, creates a regime that limits the release of ozone-depleting substances into the atmosphere. Allowing the import of such substances from non-parties would frustrate the whole system and therefore import and export from or to non-parties are banned. The Convention on International Trade in Endangered Species of Wild Fauna and Flora (CITES), on the other hand, offers an example of a treaty that incorporates trade measures to artificially control the supply of a given product to achieve its objectives. Finally, both the Montreal Protocol and the Basel Convention on the Control of Transboundary Movements of Hazardous Wastes and Other Wastes provide for more trade-restrictive measures to be adopted only against non-parties to incentivize membership. 
treaties have been featuring such provisions for decades, and there is absolutely nothing surprising in a multilateral environmental treaty providing for trade restrictions to fulfill specific environmental protection objectives. ${ }^{4}$ As environmental treaties, these instruments pursue their environmental protection goals in a variety of ways including, when deemed more effective, through the regulation of trade measures. There's nothing shocking about any of that.

What would instead be surprising is finding similar provisions within the text of trade agreements rather than environmental one-and this is precisely what this chapter will show: trade negotiations and agreements that neither ignore the environment nor expand exception clauses to accommodate environmental concerns within the hard-driving logic of trade. Rather, trade rules that have been designed with environmental protection in mind. The backdrop against which this new chapter of the trade/environment nexus unfolds is provided by the 2030 Agenda for Sustainable Development (2030 Agenda), which has fortified the acknowledgment that environmental degradation, lack of access to clean and affordable water, and spreading hunger and poverty have become the most pressing concerns faced by the international community, and that trade can play an important role in securing their solution. ${ }^{5}$ After many decades, the notion that the trade regime is meant for something greater than trade liberalization and the instrumental role of trade instruments and norms had finally resurfaced.

\section{Tables Have Turned}

What will trade be like in $203 \circ$ ?

How can we shape it to fit our priorities?

How can we make it more sustainable? roberto AZEvêdo, wTo Public Forum, October 2, 2018

In his opening speech delivered at the wTo Public Forum on October 2, 2018, Roberto Azevêdo, former Director-General of the WTO, welcomed more than 2000 people by asking his audience these difficult, yet fundamental questions. ${ }^{6}$

4 See e.g. Edith Brown Weiss, 'The Evolution of International Environmental Law' (2011) 54 Japanese Yearbook of International Law 1.

5 United Nations General Assembly, Transforming Our World: The 2030 Agenda for Sustainable Development, A/REs/70/1 (Sept. 25, 2015) [hereinafter 203o Agenda].

6 Roberto Azevêdo, wTo Director-General, Opening Remarks at the wTo Public Forum (Oct. 2, 2018). The text of the speech is available at https://www.wto.org/english/news_e/spra_e/ spra238_e.htm (last accessed August 3, 2021). 
The third question resonated in particular among the hundreds of environmentalists in the room, whether national delegates, leaders of non-governmental organizations (NGO s), businessmen, or students. This very question was given center stage throughout the day, with a series of events following one after another unremittingly, all tied together by the same theme: "Making Trade Work for the Environment, Prosperity, and Resilience."7

The idea first came to Azevêdo and Eric Solheim, former Director of United Nations (UN) Environment, about a year before, and was announced to the public in January 2018. Although over the past 20 years, the trade and environmental agendas had been slowly brought closer together, the two leaders agreed that more needed to be done. ${ }^{8}$ In his speech, Azevêdo acknowledged that "trade is a powerful tool to make green technologies more affordable and to help sustainable business expand," making it his priority to ensures that trade "delivers benefits for people and the environment everywhere." Over the course of the many events that took place on that October day in Geneva, many proposals were advanced, all pointing to ways in which trade institutions and instruments could be used and trade rules modified to foster environmental — and more broadly sustainable development-goals. Some panelists, for instance, called for trade policies in support of the widespread dissemination of environmentally friendly technologies such as those needed for renewable energy. Others debated approaches to eliminate fossil fuel subsidies, and most of them agreed on the importance of introducing new rules on subsidies in the fisheries sector. Most of these ideas seemed to be widely shared by the representatives of both the trade and environmental communities. Azevêdo himself mentioned the agreement on deep cuts in fish-depleting subsidies and the scaling back of trade barriers on environmental goods and services as examples of ways to ensure the 'sustainability' of trade. What is more, he seemed entirely confident that "the wTO [would be] the place to deliver progress on these issues." 10

This statement, and the launch, on the very same day, of a joint WTO/Un Environment publication entitled-just like the series of events-Making

The series of events were co-organized by the wTO and UN Environment. See https:// www.unenvironment.org/events/conference/making-trade-work-environment -prosperity-and-resilience (last accessed August 3, 2021).

8 Roberto Azevêdo, wто Director-General, Address at the High-Level Panel on Making Trade Work for the Environment, Prosperity, and Resilience (Oct. 2, 2018).

9 Ibid.

10 Ibid. 
Trade Work for the Environment, Prosperity, and Resilience, ${ }^{11}$ broke new ground. Not even 20 years had passed since another wто Director General, Renato Ruggiero, had penned the following words reflecting on the events that had unfolded in Seattle in November 1999: "This Organization [the wTO] cannot be allowed to gradually drift away from its trade vocation. It would serve neither the wто nor any other cause if it were to pretend it could offer solutions to every non-trade issue."12 Now, the Director General in charge looks at the WTO and sees a forum where progress on making trade work for a variety of non-trade concerns is possible, if not even desirable. And so do environmental organizations: in a meeting of the CTE in January 2008, a representative from the United Nations Environment Program (UNEP) had declared with confidence that "the Wто was the most promising international forum for effectively disciplining fisheries subsidies,"13 one of the thorniest issues at the interface between trade and the environment.

The thick lines that had been drawn by the trade policy elite to distinguish what qualified as a 'trade issue' and what did not have become increasingly blurry, to the point of nearly fading. And, while bilateral and regional trade negotiations had been addressing them since NAFTA, this was the first time the WTO itself was depicted as a forum "to deliver progress on these issues."14

The 2018 joint publication broke new ground also with regards to the previous record of cooperation between the two organizations. In 2009, Pascal Lamy and Achim Steiner, then Directors of, respectively, the WTO and UNEP, presented the first joint study ever carried out together by the two organizations, a detailed and comprehensive report on climate change and trade. ${ }^{15}$ The document, groundbreaking at the time given the decades of isolation between the two communities, still reflected the traditional trade-centered approach to the nexus: it took Wто rules for granted and addressed the question of how to best address climate change within the boundaries of international trade law, as it was based on the assumption that "there is considerable scope and flexibility under Wто rules for addressing climate change at the national level."16

11 Wто/Un Environment, Making Trade Work for the Environment, Prosperity, and Resilience (2018).

12 Roberto Ruggiero, 'Reflections After Seattle' (2000) 24(9) Fordham International Law Journal 9, 11. See also Jagdish Bhagwati, 'On Thinking Clearly About the Linkage Between Trade and the Environment' (2000) 5 Environment \& Development Economics 483.

$13 \mathrm{WT} / \mathrm{CTE} / \mathrm{M} / 45$ (Jan. 9, 2008), para. 15 .

14 Roberto Azevêdo, Address at the High-Level Panel (n 8).

15 WTo/Unep, Trade and Climate Change (2009).

16 Ibid., p. v. The Report focuses on three broad categories of national climate change policies-price and market mechanisms, financial mechanisms, and technical 
The question at the core of the new report published on October 2, 2018, on the other hand, was a significantly different one: how to best use trade policies and design trade rules that are conducive to environmental protection. ${ }^{17}$ Not only did this report represent the first output of a brand-new joint initiative by the two organizations on trade and the environment, but, most importantly, it signaled a change of course and began a new chapter in the trade/environment story.

\subsection{The Instrumental Role of Trade}

The dimension of sustainability was at the center of one of the most recent Wто Public Forums, held in Geneva in October 2018. Even the title of the Forum - 'Trade 2030' - was imbued with 'sustainability' language, as it clearly echoed the 2030 Agenda for Sustainable Development, launched in $2015 .{ }^{18}$ The latter set targets to be achieved by 2030 in areas such as poverty reduction, health, education, and the environment, and the Forum, acknowledging the role that trade can play in achieving sustainable development goals (SDG s), focused precisely on the contribution that the Wто could make to the 2030 Agenda. The launch of the 2030 Agenda, however, was not the first time that trade was recognized as a powerful tool to achieve a sustainable future.

In 2002, world leaders had gathered in Johannesburg, South Africa, to further build on the achievements made since the Conference on Environment and Development held in Rio ten years before. The Johannesburg Summit, which brought together tens of thousands of participants, from heads of State and national delegates, to leaders from NGO s, business, and many other major groups, focused on poverty eradication, changing unsustainable patterns of production and consumption, and protecting and managing natural resources. ${ }^{19}$ In this context, for the very first time, the parties recognized "the major role that trade can play in achieving sustainable development and in eradicating

requirements - and on their compatibility with trade rules. As a matter of fact, each section of the report devoted to these categories of measures provides a description of the measures first, followed by the overview of the relevant wTo rules they fall under, assessing their compatibility with them. Trade norms are here clearly used as the relevant legal framework, and climate change policies as the object to be evaluated against such framework.

17 This Report is based on the 2030 Agenda and on the assumption that trade should be "at the service of a more sustainable, inclusive, and resilient world." wTо/Un Environment, Making Trade Workfor the Environment (n 11 ) 2.

182030 Agenda.

19 See e.g. Luc Hens and Bhaskar Nath (eds.), The World Summit on Sustainable Development (Springer, 2005). 
poverty" and encouraged "members of the World Trade Organization to pursue the work program agreed at their Fourth Ministerial Conference." ${ }^{20}$

The Johannesburg Plan of Implementation, in particular, encouraged the completion of the Doha Round of negotiations suggesting, among others, the reform of the existing subsidies disciplines, in particular with reference to those subsidies "that have considerable negative effects on the environment and are incompatible with sustainable development."21 The Johannesburg Plan of Implementation therefore, for the first time, emphasized the potential role that trade rules could play in achieving sustainable development. It further added that "States should cooperate to promote a supportive and open international economic system that would lead to economic growth and sustainable development in all countries to better address the problems of environmental degradation." 22

The instrumental nature of an open and well-functioning economic system was by no means something new. In the first half of the twentieth century, Cordell Hull had been arguing fiercely that "unhampered trade dovetailed with peace, ${ }^{23}$ while fighting for the establishment of an open international economic system precisely to ensure peaceful relations among nations and avoid the horrors of the two wars. When the General Agreement on Tariffs and Trade

20 World Summit on Sustainable Development, Johannesburg, South Africa, August 26-September 4, 2002, Plan of Implementation of the World Summit on Sustainable Development, U.N. Doc. A/CONF.199/20, Annex (Sept. 4, 2002) [hereinafter Johannesburg Plan of Implementation], para. 90.

21 Ibid., para. 97(b).

22 Ibid., para. 101, first sentence. See also United Nations International Conference on Financing for Development, Monterrey, Mexico, March 18-22, 2002, Financing for development: Monterrey Consensus of the International Conference on Financing for Development: the final text of agreements and commitments adopted at the International Conference on Financing for Development, paras. 26-38; and United Nations, Follow-up International Conference on Financing for Development to Review the Implementation of the Monterrey Consensus, Doha, Qatar, Nov. 29-Dec. 2, 2008, Doha Declaration on Financing for Development: outcome document of the Follow-up International Conference on Financing for Development to Review the Implementation of the Monterrey Consensus, A/CONF.212/L.1/Rev, paras. 30-39. It should also be noted, however, that the Johannesburg Plan of Implementation takes the multilateral trade law framework for granted when it states that Countries should "establish and strengthen existing trade and cooperation agreements, consistent with the multilateral trading system, with a view to achieving sustainable development [and] support voluntary WTO-compatible market-based initiatives for the creation and expansion of domestic and international markets for environmentally friendly goods and services." Johannesburg Plan of Implementation, para. 99(a) and (b) (emphasis added).

23 Cordell Hull, The Memoirs of Cordell Hull (Macmillan, 1948), p. 81. 
(GATT) was drafted, its preamble emphasized that trade was useful only insofar as it served broader goals. ${ }^{24}$ When the WTO was established 50 years later, the instrumental role of trade was once again reaffirmed but, rather than being merely conducive to economic growth and to ensure peace among nations, it was now supposed to serve much broader social and developmental goals, in other words, sustainable development. As the years went by, the need for the trading system to pursue sustainable development goals has become more and more important, as environmental degradation, lack of access to clean and affordable water, spreading hunger and poverty have become today as pressing as ensuring peaceful inter-state relations was when Hull was arguing for the first steps towards international trade cooperation.

This message was reiterated and made even more explicit in the UN General Assembly Resolution The Future We Want, adopted in 2012, where trade appears in the list of means of implementation (together with finance, technology, capacity-building, and registry of commitments). ${ }^{25}$ The Resolution stressed the role that international trade cooperation can and should play to achieve sustainable development in all its three dimensions, ${ }^{26}$ and singled out two issues that were deemed especially relevant to frame trade as a means of implementation: subsidies and trade in environmental goods and services. ${ }^{27}$ The problem of fisheries subsidies, in particular, caught the drafters' attention as they

24 In the GATt Preamble, the Contracting Parties recognized that "entering into reciprocal and mutually advantageous arrangements directed to the substantial reduction of tariffs and other barriers to trade and to the elimination of discriminatory treatment in international commerce" was instrumental to "raising standards of living, ensuring full employment and a large and steadily growing volume of real income and effective demand, developing the full use of the resources of the world and expanding the production and exchange of goods." General Agreement on Tariffs and Trade, Oct. 30, 1947, 61 Stat. A-11, 55 U.N.T.S. 194 [hereinafter GATT], preamble.

25 G.A. Res. 66/288, U.N. Doc. A/RES/66/288 (Sept. 11, 2012) [hereinafter The Future We Want], paras. 281-2. In Rio, instead, trade does not yet feature as having any kind of instrumental role. Agenda 21, for example, does not list it among the means of implementation, as The Future We Want did in 2011. The means of implementation in the text of Agenda 21 included: i) Financial resources and mechanisms; ii) Transfer of environmentally sound technology, cooperation and capacity-building; iii) Science for sustainable development; iv) Promoting education, public awareness and training; v) National mechanisms and international cooperation for capacity-building in developing countries; vi) International institutional arrangements; vii) International legal instruments and mechanisms; viii) Information for decision-making. Agenda 21, paras. 33.1-40.30. See also the Programme for the Further Implementation of Agenda 21. G.A. Res. 19/2, U.N. Doc. A/REs/s-19/2 (Sept. 19, 1997) [hereinafter Programme for the Further Implementation of Agenda 21], paras. 76-115.

26 The Future We Want, para. 19.

27 Ibid., para. 281. 
decided to build on the commitment taken ten years prior in Johannesburg "to eliminate subsidies that contribute to illegal, unreported and unregulated [IUU] fishing and overcapacity ... and to conclude multilateral disciplines on fisheries subsidies." ${ }^{28}$ The Resolution did not stop there and went on to address the thorny issue of fossil fuel subsidies as well:

Countries reaffirm the commitments they have made to phase out harmful and inefficient fossil fuel subsidies that encourage wasteful consumption and undermine sustainable development. We invite others to consider rationalizing inefficient fossil fuel subsidies by removing market distortions, including restructuring taxation and phasing out harmful subsidies, where they exist, to reflect their environmental impacts ... ${ }^{29}$

Only three years later, world leaders, meeting at the UN Headquarters in New York, as the Organization celebrated its seventieth anniversary, embarked on a new journey agreeing on a "comprehensive, far-reaching and peoplecentered set of universal and transformative Goals and targets." ${ }^{30}$ Seventeen goals, to be precise, and 169 associated targets, which constituted "the result of over two years of intensive public consultations and engagement with civil society and other stakeholders around the world ..."31

The role of trade as a means of implementation appears in two manners in the text of the 2030 Agenda for Sustainable Development: as a specific section under the heading 'means of implementation', and as a target under some of the 17 SDG s. As to the former, the instrumental role of trade is envisioned almost exclusively with regards to the developmental component of the goals. This explains the reference being mostly to those norms and mechanisms relevant for assisting developing and least-developed countries in their path

28 Ibid., para. 173. IUU fishing was originally defined in 2001 within the context of the International Plan of Action to Prevent, Deter, and Eliminate Illegal, Unreported and Unregulated Fishing. Illegal fishing refers to fishing and related activities conducted in contravention of national, regional and international laws. Unreported fishing covers non-reporting, misreporting, or under-reporting of information on fishing operations and their catches. And unregulated fishing includes fishing by stateless vessels fishing in convention areas of Regional Fisheries Management Organizations (RFMOs) by non-party vessels, fishing activities not regulated by states and with monitoring and accounting difficulties, and fishing in areas or stocks for which there were no conservation or management measures. See FAO statement at the CTE. WT/CTE/M/63 (Sept. 27, 2017), para. 1.1.

29 The Future We Want, para. 225.

$30 \quad 2030$ Agenda, para. 2.

31 Ibid., para. 6. 
towards sustainable development, ${ }^{32}$ and therefore only indirectly linked to the environment issue. After all, environmental protection represents only one of the components of sustainable development and needs constant balance with the social and economic goals of all countries-in particular developing and least-developed ones.

Under specific SDG s, instead, trade is explicitly identified as a tool with high potential when it comes to protecting certain environmental components. Examples include enhancing "international cooperation to facilitate access to clean energy research and technology, including renewable energy, energy efficiency and advanced and cleaner fossil fuel technology,"33 rationalizing and phasing out fossil fuel subsidies "to reflect their environmental impact,"34 prohibiting "certain forms of fisheries subsidies which contribute to overcapacity and overfishing" and eliminating those "subsidies that contribute to illegal, unreported and unregulated fishing,"35 and finally enhancing "global support for efforts to combat poaching and trafficking of protected species." ${ }^{36}$ Assessed together, all these targets suggest the importance of 'greening' the economy.

\subsection{A Global Green New Deal}

The origin of the term 'green economy' can be traced back to a 1989 publication by a number of prominent economists titled Blueprint for the Green Economy, which presented, for the first time, practical proposals on how to 'green' modern economies and put them on the path to sustainable development. ${ }^{37}$ Although it was initially presented as a conceptual challenge, and was later characterized as a sub-category of sustainable development, the concept of 'green economy' differs from that of sustainable development: while the latter is all about internalizing negative environmental externalities and "doing as well in economic terms while respecting the environment", the concept of

32 Ibid., Goal 17 involves strengthening the means of implementation of the other SDG s, one of which is trade. In particular, targets 17.11 and 17.12 refer to "significantly increase[ing] the exports of developing countries, in particular with a view to doubling the least developed countries' share of global exports by 2020 " and realizing "timely implementation of duty-free and quota-free market access on a lasting basis for all least developed countries, consistent with World Trade Organization decisions, including by ensuring that preferential rules of origin applicable to imports from least developed countries are transparent and simple, and contribute to facilitating market access." See also Target 1o.a.

33 Ibid., Targets 7.a and 7.b.

34 Ibid., Target 12.c.

35 Ibid., Target 14.6.

36 Ibid., Target 15.c.

37 David Pearce et al., Blueprint For A Green Economy (Earthscan, 1990). 
'green economy' suggests an evolution towards designing a whole new economic paradigm to fit new environmental imperatives, because doing well in economic terms requires focusing on green opportunities. ${ }^{38}$

All of a sudden, protecting the environment is no longer a matter merely of 'responsibility' but rather 'profitability', and states are now urged to build their economic models on environmental considerations in order to do better in economic terms. ${ }^{39}$ Through what Esty and Winston call an 'environmental lens', moving from brown to green means moving from green to gold, as going 'green' "is not just a nice strategy tool or a feel-good digression from the real work of a company [but rather] an essential element of business strategy in the modern world." 40

The idea of a 'green economy' represents the centerpiece of the 'Global Green New Deal', launched by UNEP in 2008, which followed in the footstep of a much earlier 'New Deal'. In July 1932, Franklin D. Roosevelt flew to Chicago to accept the Democratic nomination for President. Dressed in a blue suit with a red rose in his lapel, Roosevelt made his way slowly to the podium and, facing the cheering crowd, promised a 'New Deal' for America ${ }^{41}$ And America was very much in need of a new deal. When, only a few months later, Roosevelt entered the Oval Office as President, the economic crisis was at its most terrifying: about a quarter of the country's labor force was unemployed and more than 50 million people were in desperate poverty. ${ }^{42}$ Facing the crisis head on, over the next eight years, the United States (US) government introduced a series of experimental 'New Deal' programs and projects aimed at stabilizing the economy and providing jobs and relief to the many Americans who were suffering.

On December 2, 2008, the United Nations Environment Program convened a meeting of policy experts in its offices in Geneva to discuss a comprehensive global strategy to address a new alarming crisis. By December 2008, it was

38 See Jorge E. Viñuales, 'Foreign Investment and the Environment in International Law: The Current State of Play', in Kate Miles (ed.), Research Handbook on Environment and Investment Law (Edward Elgar, 2019). See also Sha Zukang, Secretary-General of the 2012 United Nations Conference on Sustainable Development, statement at the Meeting of the CTE held on July 6, 2011, WT/CTE/M/ $5^{2}$ (Sept. 6, 2011), paras. 100-1; UNEP, Towards a Green Economy: Pathways to Sustainable Development and Poverty Eradication (2011), pp. $1-2$.

39 Viñuales, 'Foreign Investment and the Environment in International Law' (n 38 ).

40 Daniel C. Esty and Andrew S. Winston, Green to Gold (Yale University Press, 2006), p. 4.

41 Anne Schraff, Franklin Delano Roosevelt (Saddleback Educational Publishing, 20o8), p. 35.

42 Michael J. Heale, Franklin D. Roosevelt. The New Deal and the War (Routledge, 1999), pp. $17-18$. 
already apparent that the world was witnessing its worst financial crisis yet, triggering the start of one of the most severe economic recessions since the Great Depression of the 1930s. What the world needed was the same kind of initiative and government leadership that had been shown by Roosevelt and his 'New Deal', but "at a global scale and embracing a wider vision."43

First, this 'New Deal' should be global in scale, given the global scale of the crises the world was confronted with, and all countries would be invited to participate. Second, the financial crisis was just one piece of the puzzle: what the world was facing was in fact multiple crises, including climate change, rising fuel prices, and food and water scarcity. ${ }^{44}$ The policy experts gathered in Geneva agreed that these crises shared a common feature, namely the gross misallocation of capital as, over the two previous decades, "much capital [had] been poured into property, fossil fuels, and structured financial assets with embedded derivatives, but relatively little [had] been invested in renewable energy, energy efficiency, public transportation, sustainable agriculture, and land and water conservation." ${ }^{\text {45 }}$ Emerging global threats arising both from ecological crises and inequitable distribution of resources called for a new economic model "capable of delivering enhanced prosperity and growing social equity, within the contours of a finite and fragile planet." 46 Thus, what was necessary in 2008 was to avoid resurrecting an unsustainable 'brown' economy but rather promote structural changes towards an economy that is low carbon, efficient and clean in production, in other words a 'green' economy. The economic recovery promoted by Roosevelt in the 1930s was replaced by a 'global green recovery', and his 'New Deal' had become a 'Global Green New Deal', which should lead the world on a pathway towards a sustainable future.

\subsection{Trading Places: A Brief History of Means and Ends}

The objectives of this 'Global Green New Deal' were fourfold: making a major contribution to reviving the world economy, reducing carbon dependency and ecosystem degradation, putting economies on a path to clean and stable development, and furthering sustainable and inclusive growth while ending extreme poverty. ${ }^{47}$ Under this agenda, nearly all sectors of the global economy needed

43 Edward B. Barbier, A Global Green New Deal: Rethinking the Economic Recovery (Cambridge University Press, 2010), p. xvi.

44 UNE P, Global Green New Deal, Policy Brief (Mar. 20o9), pp. 2-3.

45 Ibid., p. 3.

46 PAG E, Green Industrial Policy and Trade: A Tool-Box, UN Environment and Unido under the Partnership for Action on Green Economy (2017), p. 7 .

47

UNEP, Global Green New Deal (n 44) 5. 
to be 'greened': domestic policy reforms were recommended to reduce fossil fuels and other perverse subsidies, while creating positive incentives to those sectors that encourage a green economy and appropriate taxes to account for environmental externalities.

Trade policies and other economic instruments, such as investment schemes, play a key role in developing a green, circular economy, which in turn is seen as a core component of the overall strategy to achieve sustainable development and poverty eradication in the near future, as The Future We Want clearly emphasizes. ${ }^{48}$ The picture that all these new instruments paint is significantly different from the one we were contemplating at the beginning of this book, as much has changed since the beginning of the twentieth century.

The reader certainly remembers the international treaties signed during the end of the nineteenth and the beginning of the twentieth century which, although couched in environmental terms, were aimed at the conservation of certain environmental elements as instrumental to economic growth. Thus, for instance, it was forbidden to kill certain birds—especially insectivores—or destroy their nests, eggs, or hatching, because they proved useful to agriculture ${ }^{49}$ and fur seals were protected from over-exploitation because governments had an interest in their commerce, which could only survive if their exploitation was limited and regulated. ${ }^{50}$ In other words, environmental protection was seen as a means to an (economic) end. In his first message to Congress on December 3, 1901, Theodore Roosevelt conveyed this idea loud and clear when he proclaimed that "[f] orest protection is not an end in itself; it is a means to increase and sustain the resources of our country and the industries which depend upon them. The preservation of our forests is an imperative business necessity." ${ }^{51}$ And the Atlantic Charter itself referred to the importance of access to raw materials purely for economic reasons. ${ }^{52}$

That was still a time when the environment issue had not yet entered any national or international agenda. As the previous chapters have clearly shown, once agreement was found on the importance of environmental protection and international cooperation on environmental matters began, neoliberal

48 The Future We Want, paras. $5^{6-74}$.

49 Convention for the Protection of Birds Useful to Agriculture, March 19, 1902, 191 C.T.s.

50 Arbitration between the United States and the United Kingdom related to the Rights of Jurisdiction of United States in the Bering's Sea and the Preservation of Fur Seals, August 15, 1983, XXVIII R.I.A.A. 1.002.

51 Theodore Roosevelt, First Annual Message, Dec. 3, 1901 (emphasis added).

$5^{2}$ Point Four of the Charter declared the importance of the "further enjoyment by all States ... of access, on equal terms, to the trade and to the raw materials of the world which are needed for their economic prosperity." 
ideas had become the driving force of the trading system, and failed to see that environmental protection and sustainable development represented new goals that the trading system was in the position to pursue. Coherently with this mindset, in a paper prepared for the Founex meeting on June 3, 1971, the Secretariat of the United Nations Conference on Trade and Development (UNCTAD) had identified the major fields in which environmental actions may have an impact on world trade and on international economic relations. ${ }^{53}$ Similarly, the GATT Secretariat had, the very same year, published the well-known study entitled Industrial Pollution Control and International Trade, which surveyed a number of issues that national anti-pollution measures might raise for international trade.

It took several decades - and this is the story this book has been telling so far-for the synergetic relationship between protection of the environment and trade liberalization, as well as between the respective regimes, to come to the surface, so that environmental protection can finally be portrayed no longer as a means to an (economic) end, but as one of the ultimate goals that economic instruments - trade, financial, and investment policies-are asked to pursue. ${ }^{54}$ So, nearly 45 years later, in 2015 , UNCTAD issued a policy brief on trade and climate change, which began with the words "trade policies can have an impact on the climate change mitigation efforts of countries," ${ }^{\prime 5}$ and looked into how to design trade instruments that did not hamper such efforts, while the што Public Forum featured a whole day of discussions on how to make trade work for the environment. The terms of the debate are changing, and trade instruments offer some signs of this change.

53 The Implication of Environment Measures for International Trade and Development, Background Paper prepared by the UNCTAD Secretariat (June 3, 1971) (on file with the Environmental Science and Public Policy Archives at Harvard University, Maurice F. Strong Papers, Box 40[397]).

54 In the last several years, sustainable development has become the global paradigm guiding the ongoing reform of international investment law. Developments can be seen at the level of both treaty-drafting and investment arbitration. See UNCTAD, Investment Policy Framework for Sustainable Investment, 2015. IISD, International Investment Law and Sustainable Development: Key Cases from 2000-2010 (July 2011), and International Investment Law and Sustainable Development: Key Cases from the 2010 (Oct. 2018). See also Jorge E. Viñuales, Foreign Investment and the Environment in International Law (Cambridge University Press, 2012), and Pierre M. Dupuy and Jorge E. Viñuales eds., Harnessing Foreign Investment to Protect the Environment (Cambridge University Press, 2013). At the level of case law, see e.g. Chemtura Corporation (formerly Crompton Corporation) v. Government of Canada, ICJG 464 (PCA 2010) (Aug. 2, 2010); Parkerings-Compagniet AS v. Republic of Lithuania, ICSID Case No. ARB/05/8 (Sept. 11, 2007) [hereinafter Parkerings v. Lithuania]. UnCTAD, 'Trade and Climate Change Policy Beyond 2015', Policy Brief No. 36 (Sept. 2015). 
Of course, when stating that economic instruments are starting to be framed as means to an environmental end, it should be clarified that the end is not purely environmental. Protection of the environment is just one of the components of sustainable development, and only some of the SDG S can be defined as 'environmental'. Trade, investment, and finance are therefore a means to implements all aspects of sustainable development, including but not limited to environmental ones. ${ }^{56}$

\section{$2 \quad$ Negotiating Trade Rules with the Environment in Mind}

In April 1987, delegates from 46 countries met in Geneva. It was one of the many sessions of the negotiation of the Montreal Protocol for the Protection of the Ozone Layer where the parties discussed trade restrictions. Because the Protocol created a regime that limited the release of ozone-depleting substances into the atmosphere, allowing the import of such substances from non-parties would have frustrated the whole system. For this reason, trade restrictions were seen by many of the negotiators as necessary to ensure the integrity of the regulatory framework created with the Protocol itself. After many months of discussing different proposals, representatives from the United Kingdom (UK) and the European Commission blocked further discussion until a legal expert from the GATT Secretariat could advise them on the compatibility and permissibility of the trade restrictions that were being proposed with the rules of the General Agreement. ${ }^{57}$

Not even 30 years later, on November 27, 2015, a selected group of trade and environment experts, coming from both practice and academia, met at the Maison International de l'Environnement in Geneva, not too far from the building where the events described above took place, for what turned out to be a very productive day of discussions. The meeting had been organized by UNEP and the International Institute for Sustainable Development (IISD) with a very precise objective in mind: to create a toolkit to guide negotiators of bilateral and regional trade agreements, to help ensure that their final product would contribute to national and international environmental objectives,

56 As a result, one could say that environmental protection is still a 'means' to the extent that it can contribute to the socio-economic development of developing and least-developed countries.

57 Richard E. Benedick, Ozone Diplomacy:New Directions in Safeguarding the Planet (Harvard University Press, 2009), p. 91. 
and more broadly to sustainable development. ${ }^{58}$ In other words, to offer trade negotiators the necessary (environmental) expertise to draft trade agreements that would contribute to environmental protection and preservation.

The antinomy between the two scenarios could not be more evident: in 1987, a group of environmental negotiators asked a trade expert for advice to make sure that the rules they were going to draft would not clash with the goals and rules of the trading system; in 2015, a group of environmental experts were preparing to give advice to trade negotiators to make sure that they would negotiate trade rules that would not undermine, but rather foster, environmental goals.

\subsection{Plenty of Fish in the Sea?}

Regardless of status, every nation, indeed every person in the world, has a stake in ensuring the resilience of the Ocean. Thus, whether they are fishing nations or not, all WTO members should come together in 2019 and do the right thing for people and planet by prohibiting harmful fisheries subsidies. ${ }^{59}$

PETER THOMSON, UN Secretary General's Special Envoy for the Ocean, January 8, 2019

The 2030 Agenda for Sustainable Development identifies the removal of certain fisheries subsidies as one of the instruments to achieve Goal 14 of the Agenda, namely the conservation and sustainable use of the oceans, seas, and marine resources for sustainable development:

By 2020, prohibit certain forms of fisheries subsidies which contribute to overcapacity and overfishing, eliminate subsidies that contribute to illegal, unreported and unregulated fishing and refrain from introducing new such subsidies, recognizing that appropriate and effective special and differential treatment for developing and least developed countries should be an integral part of the World Trade Organization fisheries subsidies negotiation. ${ }^{60}$

$5^{8}$ UN Environment/IISD, A Sustainability Toolkit for Trade Negotiators: Trade and Investment as Vehicles for Achieving the 2030 Sustainable Development Agenda, available at https:// www.iisd.org/toolkits/sustainability-toolkit-for-trade-negotiators/ (last accessed August 3, 2021).

59 Peter Thomson, '2019: The Year to End Harmful Fisheries Subsidies', IISD SDG Knowledge Hub (Jan. 8, 2019), available at https://sdg.iisd.org/commentary/guest-articles/2019-theyear-to-end-harmful-fisheries-subsidies/ (last accessed August 3, 2021).

60 2030 Agenda, Target 14.6. 
The first time any action was taken on this issue at the UN level dates back to a Special Session of the UN General Assembly in 1997, which recognized the urgent need to prevent and eliminate overfishing and overcapacity and called on governments to consider the impact of subsidies on the conservation and management of fisheries and start planning appropriate action. ${ }^{61}$ In the same year, the United States asked that the issue could be addressed as a matter of WTO negotiations, ${ }^{62}$ relying on a study prepared by the Food and Agriculture Organization (FAO), which showed that "the depletion of various fish stocks has occurred in virtually all coastal states throughout the world. Indeed ... this is an inevitable outcome unless appropriate controls are adopted." 63

After the United States, several other Members, which gradually began to be known with the fitting moniker 'Friends of Fish', ${ }^{64}$ proposed to work on fisheries subsidies regulations within the WTO framework. ${ }^{65}$ During this period of time, however, there was no consensus on whether an actual need for new fisheries subsidies regulations at the WTO existed. ${ }^{66}$ In July 1999, during a

61 Programme for the Further Implementation of Agenda 21, paras. 36(e) and (f).

62 Submission by the United States to the Committee on Trade and Environment, Environmental and Trade Benefits of Removing Subsidies in the Fisheries Sector, WT/CTE/W/51 (May 19, 1997). See also Environmental Benefits of Removing Trade Restrictions and Distortions. Note by the Secretariat, WT/CTE/W/67 (Nov. 7, 1997), para. 91. During the Uruguay Round, fisheries issues were discussed in the Negotiating Group on Natural Resources Based Products (NRBP s). Later, they were moved to the Market Access Group along with other subjects and, at the end of the Round, the issue of fisheries subsidies was included under the scope of the Agreement on Subsidies and Countervailing Measures. Because of the environmental aspects it involves, it immediately became a topic of discussion at the CTE. See Chen-Ju Chen, Fisheries Subsidies under International Law (Hamburg Studies on Maritime Affairs, Springer, 2010), pp. 45-6.

63 FAO, Marine Fisheries and the Law of the Sea: A Decade of Change (FAo Fisheries Department, 1993).

64 The informal term 'Friends of Fish' has been used to refer to a group of wTo Members who have spoken for special wTо regulations on fisheries subsidies. At various times, active members of the 'Friends of Fish' coalition have included Argentina, Australia, Chile, Ecuador, Iceland, New Zealand, Norway, the Philippines, Peru, and the United States.

65 See e.g. Submission by Australia to the Committee on Trade and Environment, Trade Liberalization and the Environment: A positive Agenda for Trade Reform, wT/CTE/W/105 (Feb. 2, 1999); Submission by Iceland to the Committee on Trade and Environment, On the Environmental Impact of Fisheries Subsidies, WT/CTE/W/111 (Mar. 11, 1999); Communication from Australia, Iceland, New Zealand, Norway, Peru, Philippines and United States to the General Council, Preparations for the 1999 Ministerial Conference: Fisheries Subsidies, WT / GC/w/303 (Aug. 6, 1999); Submission by Japan to the Committee on Trade and Environment, Japan's Basic Position on the Fishery Subsidy Issue, Item 6, wT/CTE/w/173 (Oct. 23, 200o). See Chen, Fisheries Subsidies (n 62) 51. 
Special Session of the General Council of the wTo, Iceland made a particularly compelling case that the Members should agree to "eliminate subsidies that contribute to fisheries overcapacity, in view of the fact that they distort trade, seriously undermine sustainable utilization of fish stocks and hamper sustainable development," ${ }^{\prime 67}$ and nearly 20 countries expressed support for the proposal, including a relatively large number of developing countries. ${ }^{68}$ Less than two years later, UNEP held a technical workshop where it was suggested to place the fisheries subsidies issue on the Agenda of the wто Ministerial Conference. ${ }^{69}$ To facilitate the CTE Members' understanding of the issues, the Committee itself held information sessions with several environmental organizations, including UNEP and the Secretariat of the Convention on Biological Diversity (СBD).$^{70}$

In 2001, the Doha Ministerial Conference responded to these proposals by calling on the Members to "clarify and improve wTо disciplines on fisheries subsidies, taking into account the importance of this sector to developing countries,"71 and specifying that the issue would form part of the negotiations on trade and the environment. ${ }^{72}$ This statement represented a considerable milestone for the wTO: "since Doha, it has been considered that the wто has an

67 Communication from Iceland to the General Council, Preparations for the 1999 Ministerial Conference: Fisheries Subsidies, wT/GC/w/229 (July 6, 1999). See also General Council Special Session 7 July 1999, WT/GC/M/ 44 (July 28, 1999).

68 Gareth Porter, 'Fisheries Subsidies and Overfishing', UNEP-Economics and Trade Unit (Feb. 12, 2001).

69 Ibid. UneP, UneP Fisheries Subsidies Workshop Geneva. Chairman's Summary (Feb. $12,2001)$.

$70 \mathrm{WT} / \mathrm{CTE} / \mathrm{W} / 187$ (Mar. 15, 2001) and WT/CTE/W/149 (June 28, 2000). In preparation to these sessions, the Secretariat of the СтE had reviewed the work done by other international organizations, such as UNEP and FAO, on the topic. WT/CTE/W/167 (Oct. 16, 2000) and WT/CTE/W/167/Add.1 (June 19, 2001).

71 Doha Declaration, para. 28. The draft Seattle Ministerial Declaration already mentioned the issue, though in passing: "In the context of these negotiations, the areas to be considered shall include, inter alia, certain subsidies that may contribute to over-capacity in fisheries and over-fishing or cause other adverse effects to the interests of Members. The work on fisheries subsidies shall be carried out in cooperation with the FAO and drawing also on relevant work under way within other intergovernmental bodies, including regional fisheries management organizations. It shall consist of (i) the identification and examination of subsidies which contribute to over-capacity in fisheries and over-fishing, or have trade-distorting effects, and (ii) the clarification and strengthening, as appropriate of disciplines under the ASCM with respect to such subsidies." Draft Ministerial Declaration as discussed in Green Room, 3 December 1999.

Doha Declaration, para. 31. 
unprecedented opportunity to help improve the environmental and economic health of the world's oceans by disciplining harmful fisheries subsidies."73

After Doha, the CTE, which had served as an important forum to understand and discuss the issue of fisheries subsidies, passed the baton to the Negotiating Group on Rules (NGR), where discussions would continue from that point on. By the time everything was ready for the Hong Kong Ministerial Conference, the focus of the negotiations had finally shifted once and for all from the question of whether there was a need for specific regulations in the fisheries sector to that of the nature and extent of such regulations. ${ }^{74}$ The Hong Kong Ministerial declaration, issued in December 2005, noted that there was broad agreement among Members to "strengthen disciplines on subsidies in the fisheries sector, including through the prohibition of certain forms of fisheries subsidies that contribute to overcapacity and over-fishing," ${ }^{, 75}$ and which also indicated that such disciplines should take the form of amendments to the Agreement on Subsidies and Countervailing Measures (АSCM) ${ }^{76}$

The 2007 Chair Text $^{77}$ and subsequent proposals by Members have generated several substantive options for amending the wTO subsidies disciplines to account for the specificities of the fisheries sector, assuming the inadequacy of the ASCM in addressing concerns regarding the fish stock depletion and possible trade-distorting effects. ${ }^{78}$ As pointed out by several Members, existing

73 Chen, Fisheries Subsidies (n 62) 58.

74 See TN/RL/9 (June 25, 2004), para. 8. In particular there was a heated discussion between the proponents of the so-called 'top-down' approach, which would have involved a blanket prohibition followed by a list of exceptions, and those advocating for a 'bottom-up' approach, consisting of a positive list of prohibited subsidies. The countries that supported a top-down approach included Argentina, Chile, Ecuador, New Zealand Peru, the Philippines and the United States, while the coalition arguing for a bottom-up approach featured Members such as Japan, Korea, Taiwan, the European Communities, and some developing country members. For a detailed analysis of these proposals, see Chen, Fisheries Subsidies (n 62) 70-76.

75 World Trade Organization, Hong Kong Ministerial Declaration, Dec. 22, 2005, Annex D: Rules I. Anti-Dumping and Subsidies and Countervailing Measures including Fisheries Subsidies, WT/MIN(05)/DEC, para. 9 .

76 Lorand Bartels and Tibisay Morgandi, 'Options for the Legal Form of a WTO Agreement on Fisheries Subsidies' (2017) International Centre for Trade and Sustainable Development, 2. Radika Kumar et al, 'The Effectiveness of Fisheries Subsidies as a Trade Policy Tool to Achieving Sustainable Development Goals at the WTO' (2019) 100 Marine Policy 132.

$77 \mathrm{TN} / \mathrm{RL} / \mathrm{W} / 213$ (Nov. 30, 2007). The Chair Text provides for an amendment of Article 3 of the ASCM, adding subparagraph (c) to the list of 'prohibited subsidies', namely "subsidies referred to in Article I of Annex VIII", which lists eight different categories of fisheries subsidies.

78 Seung Wha Chang, 'wTo Disciplines on Fisheries Subsidies: A Historic Step Towards Sustainability? (2003) 6(4) Journal of International Economic Law 879, 880. Seven 
ASCM rules "do not adequately address other negative trade, environment and development impacts of fisheries subsidies, particularly the distinctive production distortions subsidies can cause in the fisheries sector ... [while] the heterogeneous nature of fisheries products, and the diffuse nature of support to the sector, make it harder to demonstrate the existence of market distortions of the kind envisaged by existing ASCM discipline."79 In particular, the characteristics of fish products are a source of specific technical obstacles to the use of the 'serious prejudice' and 'determination of injury' provisions. ${ }^{80}$

Recently, negotiations have been reinvigorated by the 2030 Agenda, and in particular by SDG 14.6. In 2017, the Ministers at the 11th WTO Ministerial Conference in Buenos Aires agreed

to continue to engage constructively in the fisheries subsidies negotiations, with a view to adopting, by the Ministerial Conference in 2019, an agreement on comprehensive and effective disciplines that prohibit certain forms of fisheries subsidies that contribute to overcapacity and

proposals have officially been filed up until July 2017: TN/RL/GEN/186 (New Zealand, Iceland, Pakistan); TN/RL/GEN/181/Rev.1 (EU); TN/RL/GEN/189/Rev.1 (Indonesia); TN/ RL/GEN/192 (ACP Group); TN/RL/GEN/187/Rev.2 (Argentina, Colombia, Costa Rica, Panama, Peru, Uruguay); TN/RL/GEN/193 (LDC Group); and TN/RL/GEN/191 (Norway). All the proposals can be easily compared in a document prepared by the Chair of the Negotiating Group on Rules, TN/RL/W/273 (July 28, 2017), which served as a basis for discussions at the nth Ministerial Conference in December of the same year.

$79 \mathrm{TN} / \mathrm{RL} / \mathrm{W} / 3$ (Apr. 24, 2002), 1.

8o According to Article 6.3 of the ASCM, serious prejudice may arise when "the effect of the subsidy is to displace or impede the imports of a like product of another Member into the market of the subsidizing Member; (b) the effect of the subsidy is to displace or impede the exports of a like product of another Member from a third country market; (c) the effect of the subsidy is a significant price undercutting by the subsidized product as compared with the price of a like product of another Member in the same market or significant price suppression, price depression or lost sales in the same market; (d) the effect of the subsidy is an increase in the world market share of the subsidizing Member in a particular subsidized primary product or commodity as compared to the average share it had during the previous period of three years and this increase follows a consistent trend over a period when subsidies have been granted." All these instances require the determination of the likeness of two products. However, because of the heterogeneity of fish products, products from different species can sometimes be in direct competition while similar products from the same family can require different prices. As a result, it is often difficult to determine likeness with certainty. At the same time, the heterogeneity of fish products creates difficulties in establishing the unsubsidized reference prices necessary to demonstrate injury to the domestic industry of another Member or serious prejudice to the interests of another Member (ASCM Arts. 5, 6, and 15). See TN/RL/W/3 and TN/RL/ W/12 (July 4, 2002). 
overfishing, and eliminate subsidies that contribute to IUU-fishing recognizing that appropriate and effective special and differential treatment for developing country Members and least developed country Members should be an integral part of these negotiations. ${ }^{81}$

The progress since talks began in the CTE in 1997 has been considerable. While at first, arguments were on whether the existing ASCM disciplines were sufficient, soon the question became how to modify them, and recently they have turned into more and more concrete legal texts, where environmental protection plays a central role. In fact, not only is the prohibition of certain fisheries subsidies motivated by environmental reasons, but the $2018 \mathrm{draft}$ of the new proposed discipline excludes from the definition of subsidy, and therefore from the scope of the future agreement,

subsidies ... promoting sustainable fisheries ... the adoption of techniques or technology aimed at reducing the environmental impact of wild marine capture (such as by catch reduction or turtle excluder devices) or for improving compliance with fisheries management regimes aimed at sustainable use and conservation ... and for increasing resilience or reducing vulnerability to climate change [as well as] subsidies for the installation of equipment for safety or for control and enforcement purposes, and equipment fitted for the purpose of reducing environmentally harmful emissions. ${ }^{82}$

In other words, according to this formulation, fisheries subsidies that do produce a positive environmental impact would be excluded from the overall discipline. Interestingly, all the proposals submitted to the NGR envisioned such 'environmental subsidies' as carved out of the agreement, rather than listed in a GATT-style exception clause. At the same time, all proposals and discussions reflect the need to provide for special and differential (s\&D) treatment and to introduce exceptions to address the concerns raised by

81 World Trade Organization, Fisheries Subsidies. Ministerial Declaration of 13 December 2017, WT/MIN(17)/64, WT/L/1031 (Dec. 18, 2017).

$82 \mathrm{TN} / \mathrm{RL} / \mathrm{W} / 274 /$ Rev.6 (Nov. 14, 2018), proposed Art. 2(f) and (g). See also Proposal from Indonesia. Revision, TN/RL/GEN/189/Rev.1 (July 12, 2017); Submission of Cambodia on behalf of the LDC Group, TN/RL/GEN/193 (July 17, 2017); Submission from Guyana on behalf of the ACP Group, TN/RL/GEN/192 (July 14, 2017). 
some developing countries ${ }^{83}$ and, in particular, by small vulnerable coastal states. ${ }^{84}$

Although no agreement has yet been reached and negotiations seem easier said than done, the discussion of these proposals by WTO Members reflects an unprecedented attempt to impose specific obligations on the Members to protect the environment beyond the WTO's traditional focus on trade distortions. ${ }^{85}$ In creating trade rules that also protect natural resources, the WTO would fulfill the pledges made more than two decades ago in the Earth Summit's Agenda 21 to "remove or reduce those subsidies that do not conform with sustainable development objectives." ${ }^{n 6}$

\subsection{The Untapped Green Potential of the Subsides Agreement}

The proposal presented by the US in December 2020, entitled Advancing Sustainability Goals through Trade Rules to Level the Playing Field and aimed at amending Article 5 of the ASCM to add the enactment and enforcement of environmental standards below a certain level of environmental protection to

83 See e.g. Comments from the People's Republic of China on the United States Proposal on Fisheries Subsidies to the Negotiating Group on Rules, TN/RL/W/88 (May 1, 2003); Contribution to the Discussion on the Frameworkfor Disciplines on Fisheries Subsidies. Paper from Brazil to the Negotiating Group on Rules, TN/RL/W/176 (Mar. 31, 2005). Contribution to the Discussion on the Framework for Disciplines on Fisheries Subsidies. Paper from Brazil to the Negotiating Group on Rules, TN/RL/GEN/56 (July 4, 2005).

84 See e.g. Fisheries Subsidies. Submitted by Antigua and Barbuda, Belize, Fuji Islands, Guyana, the Maldives, Papua New Guinea, Solomon Islands, St. Kitts and Nevis to the Negotiating Group on Rules, TN/RL/w/136 (July 14, 2003); WTO Fisheries Subsidies Disciplines Architecture on Fisheries Subsidies Disciplines. Paper from Fiji, Papua New Guinea and the Solomon Islands to the Negotiating Group on Rules, TN/RL/GEN/57 (July 7, 2005); WTO Fisheries Subsidies Disciplines Architecture on Fisheries Subsidies Disciplines. Paper from Fiji, Jamaica, Papua New Guinea, and the Solomon Islands to the Negotiating Group on Rules, TN/RL/GEN/57/Rev.1 (Aug. 4, 2005); wTO Fisheries Subsidies Disciplines Architecture on Fisheries Subsidies Disciplines. Paper from Antigua and Barbuda, Barbados, Dominican Republic, Fiji, Grenada, Guyana, Jamaica, Papua New Guinea, St, Kitts and Nevis, St. Lucia, Solomon Islands, and Trinidad and Tobago to the Negotiating Group on Rules, TN/RL/GEN/57/Rev.2 (Sept. 13, 2005).

85 chang, 'wTo Disciplines on Fisheries Subsidies' (n 78) 882. In particular, while members have agreed on the need to prohibit subsidies contributing to IUU fishing, significant differences of view still persist as to subsidies that may contribute to overcapacity and overfishing. To bridge these different views, in March 2019, Australia and the United States proposed a cap-based approach to address these types of subsidies. See TN/RL/GEN/197 (Mar. 25, 2019).

86 United Nations Conference on Environment and Development, Rio de Janeiro, Brazil, June 3-14, 1992, Agenda 21: Programme of Action for Sustainable Development, U.N. Doc. A/CONF.151/26 (1992) [hereinafter Agenda 21], Section I, Chapter 2, paragraph 2.21(a) and Chapter 8, paragraph 8.32(b). See UNEP, 'Incorporating Resource Impact into Fisheries Subsidies Disciplines: Issues and Options, a Discussion Paper' (2004). 
the list of 'actionable subsidies' can be read under the same light as the negotiations on fisheries. ${ }^{87}$ As a matter of fact, the US proposal addresses the role that the subsidies agreement could play in making trade and trade law more sustainable from an unprecedented perspective.

As the previous chapter has described, the important role of the ASCM in this regard has been at the center of heated debates for the past few decades. Most of the arguments, however, have concentrated on the need and opportunities to include exception clauses in the text of the agreement to allow Members to introduce measures in support of their 'green' industries. These arguments, in addition to missing the heart of the problem according to the most recent literature, ${ }^{88}$ continue to be grounded in the exception-based approach to the trade/ environment nexus: whenever the environment is introduced in the debate, its space and role is envisioned as exceptional, with all the ensuing consequences. The US proposal, on the other hand, moves away from this approach. It is no longer about resurrecting the long-dormant 'green box' in Article 8 of the ASCM, which contained a carve-out for certain kinds of measures including certain environmental ones. Nor is it about introducing a brand new exception or extending existing exceptions to the text of the agreement. The focus of the proposal is instead on the role that can be played by trade remedies to advance sustainability goals through trade rules: rather than helping countries' 'green' measures by providing for a way to escape ASCM rules, what the US is suggesting is to 'punish' those countries that do not uphold certain fundamental levels of environmental protection, adding their practices to the list of actionable subsidies, under Article 5 of the Agreement.

Actionable subsidies are permissible under WTO law so long as they do not negatively harm the trade interests of other countries. ${ }^{89}$ When this happens,

87 Draft Ministerial Decision, Advancing Sustainability Goals through Trade Rules to Level the Playing Field, WT/GC/w/814, 17 December 2020. For an earlier analysis of this proposal, see Elena Cima and Makane M. Mbengue, 'ESIL Reflection-“Kind of Green”. The U.S. Proposal to Advance Sustainability through Trade Rules and the Future of the WTO' (2021) 10 (1) ESIL Reflections.

88 See e.g. Ilaria Espa, 'New Features of Green Industrial Policy and the Limits of wTo Rules: What Options for the Twenty-First Century?' (2019) 53(6) Journal of World Trade 979, and 'Dissecting the Green Component of 21st Century Industrial Policy in the Energy Sector: Implications for the wTo System' in Elena Cima and Makane M. Mbengue (eds.), A Multifaceted Approach to Trade Liberalization and Investment Protection in the Energy Sector 16-40 (Brill, 2021).

89 According to Article 5 of the ASCM, "[n]o Member should cause, through the use of any subsidy ... adverse effects to the interests of other Members, i.e.: (a) injury to the domestic industry of another Membern; (b) nullification or impairment of benefits accruing directly or indirectly to other Members under GATT 1994 in particular the benefits of concessions bound under Article II of GATT 199412; (c) serious prejudice to the interests of another Member." 
other countries have the choice between a multilateral route (adjudication) or taking unilateral actions under the review of domestic authorities against the other government's subsidy through the imposition of countervailing duties. Countervailing duties are known, together with antidumping duties and safeguards, as 'trade remedies. ${ }^{90}$ These measures consist, essentially, of increasing the price of goods imported from abroad by imposing duties on them, to eliminate the unfair advantage arising from a subsidy given by a state to its exporters. The underlying idea of the US proposal is that "industries located in certain countries benefit from weak or unenforced environmental laws and regulations by not being required to incur, and properly internalize, the costs of preventing or remediating environmental damage resulting from their production processes" ${ }^{\prime 1}$ and thus gain an unfair competitive advantage, comparable to that obtained by subsidized industries.

This is not the first time the US has adopted a similar position vis-à-vis differential—and in particular low-environmental standards. As previously described in Chapter 3, already in the early 199os, lower environmental practices were seen as conferring 'unfair' trade advantages to low-level countries' producers and it was argued that maintaining low environmental standards allowed domestic producers to incur lesser costs and was therefore compared to a subsidy or dumping practice.$^{92}$ While the attempt to qualify lower environmental standards as subsidies was not successful in the context of the Uruguay Round of negotiations that established the wто in 1995, the United States, as well as many other-mostly industrialized — countries have turned to the bilateral and regional track to address the issue of differential environmental practices. This model was pioneered by the negotiators of the North American Free Trade Agreement (NAFTA) with the so-called 'Pollution-Haven Package', and has found its way in the vast majority of recent free trade agreements. ${ }^{93}$

Should the US proposal be accepted with the adoption of a ministerial decision, such a decision could serve as a vehicle not only to integrate the principle of non-regression in the corpus of wто law, but also to introduce the observance of an 'acceptable' standard of environmental protection as a condition for compliance with wTо rules. The implications of such integration could be wide-ranging for the relationship between trade liberalization and environmental protection. To start, it would indicate a drastic change in the traditional

90 Generally on trade remedies, see Rüdiger Wolfrum et al. (eds.), wTo: Trade Remedies (Brill, 2008); Roberto Soprano, WTO Trade Remedies in International Law (Routledge, 2018).

91 Draft Ministerial Decision, Advancing Sustainability Goals.

92 See supra Chapter 3, Section 2.6.

93 See supra Chapter 4, Section 1.6. 
free-trade approach towards regulatory diversity: rather than focusing on the 'danger' that countries would set their environmental regulations and standards 'too high', thereby creating obstacles to the free flow of commerce, the US proposal stems from the fear-traditionally shared by environmentaliststhat countries would instead be tempted to set their regulations and standards 'too low', externalizing harms onto others and ultimately harming the environment. More broadly, it would represent a significant development of the traditional approach to the relationship between international trade and the environment, as it abandons the view that the environment should enter trade agreements only through narrow exceptions, but rather through the clear formulation of environmental principles. As a result, such environmental principles — such as the principle of non-regression — could influence and shape the interpretation and application of trade provisions, as well as other 'environmental' provisions already present in the text of wTO agreements. More importantly, it could suggest that the што and the legal framework it administers represent the right forum to address the long-lasting trade and environment debate — or at least a promising candidate.

\subsection{Three Ways to Protect the Environment}

The United States has been at the forefront of the efforts to push the debate forward inside, and mainly, outside of the WTO. In the context of the efforts towards constraining environmentally harmful fisheries subsidies, for instance, a significant step forward has been made by a recent agreement signed by the US with Canada and Mexico. The newly signed agreement is the United StatesMexico-Canada Agreement, known with the acronym UsmCA, but which many still refer to as 'the new NAFTA. ${ }^{94}$ An in-depth assessment of the environmental chapter of the agreement is beyond the immediate scope of this work, and so is taking part in the discussions on who's greener-NAFTA or USMCA. ${ }^{95}$ It is instead of interest to highlight a few specific provisions of the new text, one of which deals precisely with the issue of fisheries subsidies. Not only is this the first free trade agreement (FTA) addressing this thorny question; it has also done so before a final decisive agreement could be reached at the multilateral level, despite the on-going discussions. ${ }^{96}$

94 United States-Mexico-Canada Free Trade Agreement, Nov. 30, 2018 [hereinafter USMCA]. The full text of the Agreement can be found on the website of the USTR at https://ustr.gov/ trade-agreements/free-trade-agreements/united-states-mexico-canada-agreement (last accessed August 3, 2021).

95 See e.g., Scott Vaughan, 'USmCA Versus NAFTA on the Environment', IISD, available at https://www.iisd.org/library/usmca-nafta-environment (last accessed August 3, 2021). 
It would not be the first time that countries manage to include in the text of a free trade agreement provisions that proved much harder to agree on in a multilateral context. From an environmental standpoint, in particular, some of the most recent agreements seem to really be making great strides. ${ }^{97}$ It suffices to compare the agreement signed by the European Union (EU) with Switzerland in 1972, which did not contain any reference to the environment, ${ }^{98}$ with the one signed with Japan which entered into force in February 2019, and which mentions the word environment, in all its variations, 44 times, excluding the annexes. Of course, not all that glitters is gold—or, in our case, green. In many of these new agreements, the parties do acknowledge the importance of protecting and preserving the environment and agree that trade and investment in goods and services beneficial to the environment and sustainable development should be promoted, but are these provisions actually capable of protecting the environment? Do they actually require changes in trade policies and investment schemes to foster environmental goals? Let us have a look at the recent agreement between the European Free Trade Association (EFTA) and the Philippines, which features a provision that has become relatively 'standard' in recent years:

The Parties shall strive to facilitate and promote investment, trade in and dissemination of goods and services that contribute to sustainable

97 See e.g. Gehring et al, 'Climate Change and Sustainable Energy Measures in Regional Trade Agreements (RTAs). An Overview' (2013) ICTsd Issue Paper No. 3; Rafael LealArcas, 'Climate Change Mitigation from the Bottom Up: Preferential Trade Agreements to Promote Climate Change Mitigation' (2013) 7 Carbon \& Climate Law Review; Karolina Milewicz et al. 'Beyond Trade: The Expanding Scope of the Nontrade Agenda in Trade Agreements' (2016) 62(4) Journal of Conflict Resolution 743; Elena Cima, 'Promoting Renewable Energy through FTA s? The Legal Implications of a New Generation of Trade Agreements' (2018) 52(4) Journal of World Trade 663-695; and Jean-Frédéric Morin, Andreas Dür, and Lisa Lechner, 'Mapping the Trade and Environment Nexus: Insights from a New Data Set' (2018) 18(1) Global Environmental Politics 122. The most recent meetings of the CTE have also been devoting a certain 'space' for briefings on the environmental provisions in FTA s. See e.g. WT/CTE/M/58 (MAR. 23, 2015), paras. 2.50-2.6o; WT/CTE/ M/61 (Oct. 14, 2016), paras. 3.1-3.24; WT/ СтE/M/62 (Mar. 20, 2017), paras. 3.1-3.13.

98 Article 20 contains the classical exception: "The Agreement shall not preclude prohibitions or restrictions on imports, exports or goods in transit justified on grounds of public morality, law and order or public security, the protection of life and health of humans, animals or plants, the protection of national treasures of artistic, historic or archaeological value, the protection of industrial and commercial property, or rules relating to gold or silver. Such prohibitions or restrictions must not, however, constitute a means of arbitrary discrimination or a disguised restriction on trade between the Contracting Parties" (emphasis added). 
development, such as environmental technologies, sustainable renewable energy, as well as goods and services that are energy efficient, ecolabelled or subject to schemes such as fair and ethical trade. Related nontariff barriers will be addressed as part of these efforts. ${ }^{99}$

As it is evident from the wording of this provision, while it clearly depicts the intentions of the parties, it is phrased in hortatory rather than mandatory terms and therefore is not concretely capable of contributing to environmental protection or preservation. ${ }^{100}$ These types of norms are of course important, similar to preambles, in making explicit the intentions of the parties and in guiding the interpreter in case a dispute arises. They might even lead to a 'greener' interpretation of other provisions of the same agreement, as the previous chapter has shown. However, they do not bind the parties in any way, they do not commit them to actually "facilitate and promote investment, trade in and dissemination of goods and services that contribute to sustainable development."

At a closer look, however, there are a handful of agreements that have begun including provisions that do have this concrete capability. Despite their small number and the difficulties in tracking the actual impact on environmental protection policies (since they have been concluded so recently), these efforts do point to possible avenues to be further explored by negotiators in the future. Three avenues, in particular, are worth examining.

First, provisions that require the parties to eliminate certain trade measures for environmental reasons. A notable example is Article 24.20 of the newly signed USMCA, which prohibits subsidies that contribute to overfishing. More

99 Free Trade Agreement \& Economic Integration Agreement, EFTA-Philippines, Apr. 28, 2016, Art. 11.7 (emphasis added). Other examples include e.g. Free Trade Agreement \& Economic Integration Agreement, EFTA-Georgia, June 27, 2016, Art. 10.8; Free Trade Agreement, EU-SADC, June 10, 2016, Art. 10; Free Trade Agreement \& Economic Integration Agreement, Republic of Korea-New Zealand, Mar. 23, 2015, Art. 16.4; Free Trade Agreement \& Economic Integration Agreement, Canada-Republic of Korea, Sept. 22, 2014, Art. 17.4; Free Trade Agreement, E FTA-Bosnia Herzegovina, June 24, 2013, Art. 39; Free Trade Agreement, Switzerland-China, July 6, 2013, Art. 12.3.

100 Similar hortatory language can be found in those provisions where the parties, rather than simply committing to uphold existing levels of environmental protection, decide to go even further and commit to achieve high levels of environmental protection, further clarifying the they "shall strive to continue to improve those laws" over time. See e.g. Free Trade Agreement \& Economic Integration Agreement, EU-Republic of Korea, Oct. 6, 2010 [hereinafter EU-S. Kor. FTA], Art. 13.3; Free Trade Agreement, United States-Jordan, Oct. 24, 2000, Art. 5; and Free Trade Agreement \& Economic Integration Agreement, United States-Singapore, May 6, 2003, Art. 18.1. 
precisely, two categories of subsidies are prohibited: those "provided to a fishing vessel or operator while listed for IUU fishing" and those "for fishing that negatively affect fish stocks that are in an overfished condition." ${ }^{101}$ A second example is the commitment to gradually phase out fossil fuel subsidies, which can be found in the agreement between the EU and Singapore. ${ }^{102}$

Second, provisions that recognize the parties' right to adopt certain trade measures for environmental reasons. This category of provisions can be seen as including the exemptions or carve-outs surveyed in the previous chapter. These provisions recognize the countries' autonomous right to pursue environmental objectives and, being drafted as exemptions rather than exceptions, as already explained, can potentially facilitate the adoption of domestic traderelated environmental measures. In this context, the EU-Singapore FTA stands out once again, as it allows the two parties to provide for subsidies that do have trade effects on the other party—as long as such effects are contained and the subsidy is limited to the minimum needed to achieve the objectivewhen such subsidies are necessary to achieve an objective of public interest, explicitly including subsidies "for environmental purposes." 103 The allowance of 'environmental' subsidies can also be found in the agreement between the EU and South Africa, as well as in the one with the European Economic Area (EEA). A different example is provided by article 24.17(3) of the USMCA, which allows the three parties to the agreement to adopt measures that would restrict import of fish or fish products in order to protect or conserve fish or other marine species, as long as the measures are:

101 USMCA, Art. 24.20(1). The explanatory notes to the article further clarify that "the negative effect of such subsidies shall be determined based on the best scientific evidence available" and that "a fish stock is overfished if the stock is at such a low level that mortality from fishing needs to be restricted to allow the stock to rebuild to a level that produces maximum sustainable yield or alternative reference points based on the best scientific evidence available."

102 EU-Sing. FTA, Art. 13.11(3). The commitment is followed by a caveat clarifying that such a reduction should "be accompanied by measures to alleviate the social consequences associated with the transition to low carbon fuels."

103 EU-Sing. FTA, Art. 12.8, Annex 12-A(e). See also Free Trade Agreement, EU-South Africa, Oct. 11, 1999, Annex IX. Another example is provided by the EEA. Article 61, which regulates state aid, prohibits "any aid granted by EC Member States, EFTA States or through State resources in any form whatsoever which distorts or threatens to distort competition by favouring certain undertakings or the production of certain goods ... in so far as it affects trade between Contracting Parties." However, under Article 61.3(c), "aid to facilitate the development of certain economic activities or of certain economic areas, where such aid does not adversely affect trading conditions to an extent contrary to the common interest" may be compatible with the functioning of the Agreement. 
(a) based on the best scientific evidence available, as applicable, that establish a connection between the products affected by the measure and the species being protected or conserved;

(b) tailored to the conservation objective; and

(c) implemented after the importing Party has:

(i) consulted with the exporting Party, in an effort to resolve the issue cooperatively; and

(ii) provided a reasonable opportunity for the exporting Party to take appropriate measures to address the issue. ${ }^{104}$

Third, provisions that allow the parties to streamline environmental criteria in domestic laws and policies. These include provisions that allow the parties to take environmental considerations into account in their public procurement assessments. Government procurement practices are generally considered non-tariff barriers and all the agreements that choose to regulate them contain a blanket prohibition to prepare, adopt, or apply technical specifications, or to prescribe conformity assessment procedures, as they might create unnecessary obstacles to international trade. ${ }^{105}$ Some of the more recent agreements, however, exclude from this general prohibition technical specifications adopted for environmental reasons. Article 19.9 of the EU-Canada Comprehensive Economic and Trade Agreement (CETA), for instance, allows the parties to "adopt or apply technical specifications to promote the conservation of natural resources or protect the environment"106 and, despite the general prohibition to do so, further clarifies that the "evaluation criteria set out in the notice of intended procurement or tender documentation may include" among other factors, "environmental characteristics." ${ }^{107}$ This 'exemption' is in line with the European long-term vision for sustainable development, set out in a 2011 Communication of the Commission, where one of the actions refers precisely to "make better use of public procurement to favor environmentallyfriendly products and services." 108 While traditionally 'government procurement' provisions in FTAs were focused on avoiding discrimination and

\footnotetext{
104 USMCA, Art. 24.17(3).

105 The prohibition generally reads: "A procuring entity may not prepare, adopt, or apply any technical specification or prescribe any conformity assessment procedure with the purpose or the effect of creating unnecessary obstacles to trade between the Parties" (or similar language).

106 Free Trade Agreement \& Economic Integration Agreement, Canada-EU, Oct. 30, 2016 [hereinafter CETA], Art. 19.0(6).

107 CETA, Art. 19.o(9) (emphasis added).

108 Commission Communication on a Sustainable Europe for a Better World: A European Union Strategy for Sustainable Development, May 15, 2001, Сом(2001)264 Final, 7.
} 
offsets in tenders, these new provisions can allow governments to incorporate environment-related criteria into their traditional cost-benefit analysis. ${ }^{109}$

To these three categories of provisions, we should add those that allow the parties to impose trade sanctions in case a norm in the environmental chapter or annex of the agreement is violated, and which, more broadly, provide for the enforcement of their environmental and trade provisions on the same basis. These provisions have been gradually introduced in recent FTA s signed by the US and have proven particularly effective, as the next section will show, in the context of the protection of forests.

\subsection{Trade Sanctions and Forests Protection}

In the past few decades, the number of 'environmental' provisions contained in free trade agreements has exponentially increased. ${ }^{110}$ Besides the recognition of the parties' right to pursue environmental objectives, all the main environmental principles have found their way in the text of many FTA s and, next to the classical free-trade obligation, many FTA s feature environmental obligations as well. The final section of the previous chapter has provided the reader with an overview of these provisions. Despite their undeniable potential in terms of promoting environmental protection, however, they often fall short because of a number of reasons, in particular related to their enforcement-or lack thereof.

First, in case of violation by one of the parties of the FTA's environmental norms, the parties generally have limited or no access to the general dispute settlement mechanism provided for in the agreement. Under the US-Chile FTA for instance, the parties have access to the general dispute settlement mechanism provided for in Chapter 22 of the Agreement only in the case where one of the parties has failed "to effectively enforce its environmental laws, through a sustained or recurring course of action or inaction, in a manner affecting trade between the Parties" and only after having exhausted the consultation procedure described in the environmental chapter. ${ }^{111}$ Similarly, FTA s signed by the European Union expressly clarify that the title on sustainable development is not subject to the title on dispute settlement. ${ }^{112}$

109 Climate Change and Trade Agreements: Friends or Foes? Report by The Economist Intelligence Unit (2019), 25-6.

110 See e.g. Cima, 'Promoting Renewable Energy through FTAs' (n 97) and Morin, Dür, and Lechner, 'Mapping the Trade and Environment Nexus' (n 97).

111 Free Trade Agreement \& Economic Integration Agreement, United States-Chile, June 6, 2003, Art. 19.6(8) and (9).

112 See e.g. EU-S. Kor. FTA, Art. 13.6; EU-Sing. FTA, Art. 13.16(1); and CETA, Art. 24.16. 
Various environmental — or sustainable development — chapters of FTA s do provide for their own procedure in case a violation of one of their provisions is believed to have occurred. However, these procedures generally involve several rounds of consultations and do not allow for the imposition of sanctions. The result is that the environmental chapter of FTA s, despite all these new provisions and obligations, is hardly enforceable.

A series of recent events that have unfolded under the trade agreement signed between the United States and Peru, on the other hand, seem to tell a rather different story. This story is where a trade agreement was used as a legal basis to impose a trade sanction on one of the parties because of noncompliance with its own environmental norms. The story started in 2015 in Tampico, Mexico, on an October morning. The cargo ship Yacu Kallpa, which was scheduled to arrive in Houston with lumber harvested from the Amazon rain forest, was ambushed by Homeland Security investigators, who seized the entire cargo: "never before had so much lumber been denied entry at a US port on evidence that it was harvested illegally," read a newspaper describing the events. ${ }^{113}$ Because most of the shipment belonged to the Peruvian company Inversiones La Oroza SRL (Oroza), then-US Trade Representative Michael Forman asked Peru to verify whether specific shipments from that particular company complied with Peru's laws and regulations governing the harvest and trade in timber products. ${ }^{114}$ The timber verification process initiated shortly thereafter by Peru's Supervisory Agency for Forest and Wildlife Resources (OSINFOR) found that significant portions of the wood had been harvested illegally. Given the outcome of the verification, on October 19, 2017, then-US Trade Representative Robert Lighthizer directed the US Customs and Border Protection to block all shipments from Oroza for three years or until the Interagency Committee on Trade in Timber Products from Peru determines that Oroza complied with all applicable laws, regulations, and other measures of Peru governing the harvest of and trade in timber products. ${ }^{115}$

The trade sanction imposed by the United States against Oroza's exports represented a step forward in the battle to preserve tropical forests and fight organized criminal logging in Peru. The sanction, just like the US request that Peru verified the company's compliance with Peru's environmental and timber

113 Frank Bajak, 'Investigations Show Peru Backsliding on Illegal Logging', Houston Chronicle, Apr. 19, 2017.

114 Letter from Michael B.G. Froman, US Trade Rep., to Magali Silva Velarde-Alvarez, Minister of Trade and Tourism, Republic of Peru (Feb. 26, 2016). Law No. 29763, July 22, 2011 (Peru).

115 Press Release, Office of the US Trade Rep., USTR Announces Unprecedented Action to Block Illegal Timber Imports from Peru (Oct. 19, 2017). 
laws, were not triggered or motivated by an environmental treaty. Rather, they had been adopted within the framework created by the PTPA, the United States-Peru Trade Promotion Agreement. Similarly, it was the PTPA that had led to the establishment of osinfor in Peru, "as an independent and separate body responsible for the supervision and oversight of forest and wildlife resources primarily at the point of harvest." ${ }^{\prime 16} \mathrm{~A}$ free trade agreement, in other words, had led to the creation of an institutional framework precisely devoted to forest and wildlife protection, had pushed Peru to modify and update its environmental laws, and had formed the legal basis to block the entry in the US market of illegally-harvested timber.

All these provisions can be found in an Annex to the agreement, known as the 'Forest Annex', which was drafted to help the parties "combat trade associated with illegal logging and illegal trade in wildlife,"117 incorporating and further elaborating on the 1973 Convention on International Trade in Endangered Species of Wild Fauna and Flora (CitEs). Paragraph 3 of the Annex requires Peru to take a number of actions within 18 months after the entry into force of the Agreement, some of which have an impact on trade, such as imposing penalties to deter violations of any timber laws and regulations, including "suspending the right to export the product as to which a law, regulation, or other measure has been violated,"118 and establishing "an annual export quota for bigleaf mahogany, covering logs, sawn wood, veneer sheets and plywood, at a level and in a manner consistent with Article IV of [CITEs]."119

Paragraph 7 further provides that

on the written request of the United States, Peru shall verify whether, with respect to a particular shipment of timber products from Peru to the United States, the exporter or producer of those products has complied with applicable laws, regulations, and other measures of Peru governing the harvest of, and trade in, those products. ${ }^{120}$

116 US Interagency Committee on Trade in Timber Products from Peru, Statement Regarding Implementation of the PTPA Forest Annex and Peru's July 2018 Verification Report (Sept. 17, 2018).

117 PTPA, Annex 18.3.4 on Forest Sector Governance [hereinafter PTPA Forest Annex], para. 1.

118 Ibid., para. 3(c)(ii).

119 Ibid., para. $3(\mathrm{f})$.

120 Paragraph 7 further specifies in a footnote that "the United States may detain a shipment which is subject to a verification request pending the result of the verification ...". 
If such request is made, Peru is then required to provide the United States with a written report on the results of the verification. ${ }^{121}$ If the report shows the existence of violations or if Peru fails to provide it, the United States can take a number of actions, including "denying entry to the shipment that was the subject of the verification." ${ }^{\prime 22}$ And, for the very first time in the history of US free trade agreements, the United States Trade Representative (USTR) indeed denied entry of a shipment on environmental grounds-because the timber had been harvested illegally and unsustainably.

All this was possible thanks to the historic May 10 Agreement. ${ }^{123}$ On May 10, 2007, after several months of behind-the-scene negotiations between the Democrats and the Republican Administration, a bipartisan deal on US trade policy was finally struck, less than two months before the trade promotion authority was expected to expire, and which would have been difficult to renew without the support of the pro-labor and pro-environment Democrats. ${ }^{124}$ The May 10 Agreement contains a template to be followed by any future US trade agreement with regards to six topics, including the environment. ${ }^{125}$ It further incorporates a specific list of multilateral environmental agreements, ${ }^{126}$ adding that any violation of these environmental obligations shall be enforced "on the same basis as the commercial provisions" of FTA s, including through trade sanctions:

We have agreed that all of our FTA environmental obligations will be enforced on the same basis as the commercial provisions of our agreements - same remedies, procedures, and sanctions. Previously, our environmental dispute settlement procedures focused on the use of fines, as opposed to trade sanctions, and were limited to the obligation to effectively enforce environmental laws. ${ }^{127}$

\footnotetext{
121 PTPA Forest Annex, para. 12.

122 Ibid., para. 13(a)(i).

123 Office of the US Trade Representative, Bipartisan Agreement on Trade Policy (May 2007). See H. Rep. 110-421 (Nov. 5, 2007) (describing the May 10 Agreement).

124 See Sunjoon Cho, 'The Bush Administration and Democrats Reach a Bipartisan Deal on Trade Policy', 11(15) ASIL Insights (May 31, 2007); Steven R. Weisman, 'Bush and Democrats in Accord on Trade Deals', New York Times, May 11, 2007.

125 The other areas covered are labor, investment, government procurement, intellectual property, and port security.

126 The listed MEAs are: Convention on International Trade in Endangered Species, Montreal Protocol on Ozone Depleting Substances, Convention on Marine Pollution, InterAmerican Tropical Tuna Convention, Ramsar Convention on Wetlands, International Whaling Convention, and Convention on Conservation of Antarctic Marine Living Resources. USTR, Bipartisan Agreement on Trade Policy (May 2007).
} 
Further, it contains specific reference to the PTPA, where it provides that "we have agreed to work with the Government of Peru on comprehensive steps to address illegal logging, including of endangered mahogany, and to restrict imports of products that are harvested and traded in violation of CITES." ${ }^{28} \mathrm{On}$ this basis, the United States and Peru drafted the environment chapter of the PT PA and its 'Forest Annex' clarifying that the Annex was subject to the general dispute settlement procedure, set out in Chapter 21, in contrast with all the agreements signed by the US before 2007, where their environmental provisions were subject to a special procedure in case of non-compliance, generally considered far less effective that the one foreseen in case of violation of one of the trade norms. Similarly, the PTPA and its Annex foresee the possibility to impose trade sanctions and import/export restrictions, a possibility that was used in 2017 for the very first time.

Moreover, in January 2019, the USTR requested its very first consultation under the PTPA, where the United States expressed their concern that Peru's decision to move osinfor within Peru's Ministry of Environment would have deprived the Agency of its independence, required by the 'Forest Annex', and resulted in Peru's decision to annul the decree at stake only a few months later. ${ }^{129}$

\subsection{A New Kind of Environmental Bargain}

When Canada began negotiating a trade agreement with the United States in 1986, the country's system for regulating pesticides was significantly more stringent than the one in force in the US. The latter relied on a risk-benefit regulatory model for pesticide registration, which had been opposed by environmental groups both in Canada and in the US. ${ }^{130}$ As part of the 'bargain' required to complete the negotiations, however, Canadian negotiators agreed to "work towards equivalence" with the US system, which meant settling for lower levels of environmental protection. ${ }^{131}$ In order to be able to strike a deal

128 Ibid. (emphasis added).

129 Press Release, Office of the US Trade Representative, USTR Requests First-Ever Environment Consultation Under the US-Peru Trade Promotion Agreement (PTPA) (Jan. 4, 2019); Press Release, Office of the US Trade Representative, USTR Successfully Resolves Concerns Raised in First-Ever Environment Consultation Under the US-Peru Trade Promotion Agreement (PTPA) (Apr. 9, 2019).

130 Steven Shrybman, 'International Trade and the Environment: An Environmental Assessment of the General Agreement on Tariffs and Trade' (1990) 20(1) The Ecologist 30, 33 .

131 Chapter six and seven of USCFTA required the parties to harmonize technical and agricultural standards. 
with the United States, Canada had to lower its own environmental standards. This kind of bargain reflected the traditional neoliberal approach to trade and the environment, an approach where trade liberalization is regarded as the supreme goal and differences in domestic (environmental) standards as dangerous trade barriers.

After all, despite the vocal opposition of environmental groups on both sides of the border, advisory committees had been established to assist with the negotiations, and no environmentalists had participated in their discussions, nor had they been invited to do so. ${ }^{132}$ Rather, such advisory committees were predominantly composed of representatives of government and business, while environmental and consumer groups were generally left out. This is a classic example of the 'club model' of negotiation and cooperation, as constructivists would describe it. ${ }^{133}$ It is based on a clear-cut distinction between issue-areas and on the premise that each club-trade, environment, labor etc.-is strictly responsible for its own issue-area, hence the tendency to exclude outsiders from the negotiations.

In December 2003, when the United States concluded its trade negotiations with Chile, the overall situation was significantly different. The clinical isolation between the trade and environmental communities had come to an end, as the trade community struggled to maintain its previous clubiness and was 'forced' to involve several groups of 'outsiders' in its work. In 2002, the US Congress passed the new Trade Act, which, in Section 2104(e), required that advisory committees provided the President, the US Trade Representative, and Congress with reports required under Section 135(e)(1) of the Trade Act of 1974, as amended, not later than 30 days after the President notified Congress of his intent to enter into an agreement. ${ }^{134}$ One of these advisory committees is the Trade and Environment Policy Advisory Committee or TEPAC, which had been created in 1994 and was co-chaired by the US Trade Representative and the Environmental Protection Agency (EPA) Administrator. ${ }^{135}$ In particular,

\footnotetext{
132 Shrybman, 'International Trade and the Environment' ( $\mathrm{n} 130$ ) 33.

133 See Robert O. Keohane and Joseph S. Nye Jr., 'The Club Model of Multilateral Cooperation and Problems of Democratic Legitimacy', in Roger B. Porter et al. (eds.), Efficiency, Equity, and Legitimacy: The Multilateral Trading System at the Millennium (Brookings Institution Press, 2001), pp. 264-291.

134 Trade Act of 2002, H.R. 3009, 116 Stat. 933, 19 U.S.C. $\$ \S 3803-3805$ (2002) [hereinafter 2002 Trade Act].

135 The other committees include a broad-based Advisory Committee for Trade Policy and Negotiations, a policy advisory committee on industry and one on agriculture, five technical advisory groups on specific agricultural groups, 17 industry sector advisory committees, four industry functional advisory committees, and an intergovernmental policy advisory committee.
} 
with regards to the report to be submitted by TEPAC, the Trade Act of 2002 elucidated the principal trade negotiating objectives related to environmental matters, which included (i) "to ensure that a party to a trade agreement with the United States does not fail to effectively enforce its environmental laws,"(ii) "to strengthen the capacity of United States trading partners to protect the environment through the promotion of sustainable development," and (iii) "to reduce or eliminate government practices or policies that unduly threaten sustainable development."136

In addition, Section 2012(c)(4) of the 2002 Trade Act, together with Executive Order 13,141, require the UST R to conduct several environmental reviews before a trade agreement can successfully be signed. The scope of the review is quite broad and encompasses not only an analysis of the potential impacts of the trade agreement on the environment of the parties involved but it also involves an assessment of their existing environmental legal framework.

At the time of the negotiations, Chile's environmental laws were not as advanced and as protective of the environment as US laws, or as many MEA $\mathrm{S}$ would have required. For instance, the country did not have adequate legislation to implement the basic requirements of CITES. ${ }^{137}$ To this end, in addition to Chapter 19 of the US-Chile FTA, dedicated to the environment, the parties negotiated an environmental side agreement, which, at Article II, established the Joint Commission for Environmental Cooperation, co-chaired by designated high-level officials of the US Department of State and the Chilean Ministry of Foreign Affairs and which would serve as a forum of cooperation between the two countries to work side by side to promote "sustainable development and management of environmental resources, including wild fauna and flora, protected wild areas, and other ecologically important ecosystems."138 For several years, the US-Chile cooperation conducted through the Joint Commission focused, among others, on strengthening and improving Chile's environmental legal framework and in 2016, Law 20962, which implements CITES, was approved, introducing various adaptations to national legislation in matters of prevention, control and sanction of behaviors related to trafficking and commercialization of threatened species of wild fauna and flora. ${ }^{139}$ In 2017, after a thorough review, the cites Secretariat concluded that Chile's new wildlife

\footnotetext{
1362002 Trade Act.

137 USTR, 2018 Trade Policy Agenda and 2017 Annual Report of the President of the United States on the Trade Agreements Program (Mar. 2018), 68.

138 US-Chile Joint Commission for Environmental Cooperation, 2012-2014 Work Program, 2012.

139 Law No. 20962, Sept. 3o, 2016, Diario Oficial [D.o.] (Chile).
} 
law fully satisfied the country's implementation commitments under CITES. As the two countries had committed in the 2015-2017 Joint Commission Work Program, signed in August 2015, they have succeeded in working together to preserve and protect the environment through the FTA Environment Chapter and the Environmental Cooperation Agreement. ${ }^{140}$

The two negotiations depicted could not be more different. In 1986, Canada had to agree to lower its own environmental standards to be able to successfully conclude a trade agreement with the United States. Not even 20 years later, Chile had to commit to improve its environmental legal frameworkin particular in the area of protection of threatened species of wild flora-to conclude an agreement with, once again, the United States. While in 1986 harmonization of domestic standards and regulations was feared by environmentalists as it tended to occur downward, in 2003 it showed the potential to occur upward.

\subsection{The EU's Sustainable Commercial Policy}

A similar approach can be found in the Resolution on Climate Diplomacy adopted by the European Parliament on July 3, 2018. The latter called on the Commission "to integrate the climate change dimension into international trade and investment agreements and to make ratification and implementation of the Paris Agreement a condition for future trade agreements", while recommending the "development and systematic inclusion of a mandatory fundamental climate change clause in international agreements, including trade and investment agreements." ${ }^{141}$ Certain environmental requirements are set out as conditions to negotiate comprehensive trade agreements with the European Union, while only 12 years before, the Communication Global Europe: Competing in the World, had identified purely economic criteria to

140 Joint Communique of the United States-Chile Environment Affairs Council and Joint Commission for Environmental Cooperation (Aug.13, 2015).

141 Climate Diplomacy Resolution. These statements were later repeated by the European Parliament after the 2018 Climate Change Conference in Katowice: European Parliament Resolution on the 2018 UN Climate Change Conference in Katowice, Poland (COP24), Oct. 25, 2018, para. 53. The recent decision of the European Council to begin new trade talks with United States irrespective of Trump's decision to withdraw from the Paris Agreement and despite the unfavorable vote of the European Parliament on this point, has been justified arguing that the condition set out in the Climate Diplomacy Resolution only applies to 'comprehensive trade agreements', while the current trade negotiations between the EU and the US will only cover industrial tariffs and conformity assessments. Opening of Negotiations between the EU and the US, 2019/2537(RSP) (Procedure Rejected). Council Decision 6052/19 (Apr. 9, 2019). 
guide the EU in the selection of partners in FTA s and in their negotiation and conclusion, namely: "the market potential measured in terms of size and economic growth, the level of protection vis-à-vis exports from the EU (customs tariffs, non-tariff barriers), etc., [as well as] negotiations between the EU's potential partners and its competitors, the impact of these negotiations on the EU and the risk that they pose to the partners' preferential access to the Union's markets." 142

At the same time, however, the Communication had also recognized the role that trade cooperation can have in promoting sustainable development when it stated that "in considering new FTA s, we will need to work to strengthen sustainable development through our bilateral trade relations. This could include incorporating new co-operative provisions in areas relating to labor standards and environmental protection."143

In the same year, the Council of the European Union adopted the Sustainable Development Strategy:

21. The EU will seek to use the full range of policy instruments in the implementation of its policies. The most appropriate economic instruments should be used to promote market transparency and prices that reflect the real economic, social and environmental costs of products and services (getting prices right). Their potential to reconcile environmental protection and smart economic growth and exploit win-win opportunities should be recognized. Additionally, their suitability should be judged against a set of criteria, including their impact on competitiveness and productivity.

22. Member States should consider further steps to shift taxation from labor to resource and energy consumption and/or pollution, to contribute to the EU goals of increasing employment and reducing negative environmental impacts in a cost-effective way. ${ }^{144}$

142 Commission Communication on Global Europe: Competing in the World, Oct. 4, 20o6, $\operatorname{com}(2006) 567$.

143 Ibid.

144 Council Review of the EU Sustainable Development Strategy, June 9, 2006, 10117/o6. See Commission Communication on a Sustainable Europe for a Better World: A European Union Strategy for Sustainable Development, May 15, 2001, СОМ(2001)264 Final. See also the Treaty of Nice, Declaration on Article 175 of the Treaty establishing the European Community: "The High Contracting Parties are determined to see the European Union play a leading role in promoting environmental protection in the Union and in international efforts pursuing the same objective at global level. Full use should be made of all possibilities offered by the Treaty with a view to pursuing this objective, including the use of incentives and instruments which are market-oriented and intended to promote 
The centrality of environmental protection-and sustainable development more broadly_as inherent component of the EU commercial policy, was finally clearly stated by the European Court of Justice in its May 2017 Opinion $2 / 15 \cdot{ }^{145}$ Asked about the competence of the EU with regards to the EU-Singapore FTA, the Court, disagreeing with the Advocate General, stated that sustainable development clauses in FTA s fall under EU exclusive competence and that there is an "obligation on the European Union to integrate those objectives and principles into the conduct of its common commercial policy" stemming from the first paragraph of Article 207 of the Treaty on the Functioning of the European Union (TFEU) itself, Article 21 of the Treaty of the European Union (TEU) and Articles 9, 11 and 205 TFEU. ${ }^{146}$ The argument goes on with the Court taking a clear position in favor of the entire sustainable development clause having a direct and immediate effect on trade between the EU and Singapore. ${ }^{147}$

\subsection{From Exception to Promotion}

In 1994, when NAFTA was adopted, it was welcomed as the "greenest trade agreement ever negotiated." ${ }^{148}$ And it was, at the time. These few paragraphs, however, show us a very different meaning of 'being green'. It is not simply a matter of allowing countries to protect the environment within the rigid boundaries of trade rules anymore. It is instead a matter of designing trade rules that are themselves conducive to environmental protection. New provisions in trade agreements-and even entire agreements if a WTO agreement on fisheries will one day be completed—are now explicitly prohibiting certain

sustainable development." Treaty of Nice amending the Treaty on the European Union, the Treaties Establishing the European Communities and Certain Related Acts, 2001 O.J. C $80 / 1$.

145 ECJ, Opinion 2/15, May 16, 2017.

146 Ibid., para 143. See also Opinion of Advocate General Sharpston, Dec. 21, 2016. According to Article $207 \mathrm{TFEU}$, "the common commercial policy shall be conducted in the context of the principles and objectives of the Union's external action." Article 9 and 11 of the TEU read: "in defining and implementing its policies and activities, the Union shall take into account requirements linked to the promotion of a high level of employment, the guarantee of adequate social protection, the fight against social exclusion, and a high level of education, training and protection of human health" (Article 9) and "Environmental protection requirements must be integrated into the definition and implementation of the Union's policies and activities, in particular with a view to promoting sustainable development" (Article 11).

147 Giovanni Gruni, 'Towards a Sustainable World Trade Law? The Commercial Policy of the European Union after Opinion 2/15 CJEU' (2018) 13 Global Trade \& Customs Journal 5, 6.

148 Carla A. Hills, 'The Trade Pact is Our Best Deal', New York Times, Aug. 17, 1993. 
trade measures because they harm the environment and recognize the right of the parties to restrict trade in the name of environmental protection. In the past-when NAFTA or the WTO agreements were being negotiatedthese kinds of provisions could only be found in multilateral environmental agreements.

To really appreciate the groundbreaking nature of these developments, let us consider the case of the protection of wild flora. Certain plant species, threatened with extinction or otherwise endangered, have been protected since 1975 by the Convention on International Trade in Endangered Species. ${ }^{149}$ The Convention places certain controls on international trade in specimens of selected species, dividing them in two groups-Appendix I, for "species threatened with extinction which are or may be affected by trade" and Appendix II for species which might become threatened with extinction if their trade remains unregulated. ${ }^{150}$ The listing of timber species under CITES, for instance, places an obligation on the exporting state willing to export a CITEs-listed timber species to demonstrate the legal acquisition of the listed timber in accordance with national law, and provide a scientific non-detriment finding attesting to the sustainability of the amount of listed timber harvested. In parallel, the importing state has the obligation not to accept any listed timber species without the necessary permits and to seize and confiscate any illegally traded listed timber species. ${ }^{151}$

I

When the GATT was negotiated in 1947, no reference was made in the text of the agreement to the protection of forests, timber, or wild fauna and flora more broadly, not even after the WTO was established in 1994. When the issue of natural resources and natural resource-derived products was raised during the Uruguay Round, the discussion, far from addressing the need to protect natural resources, revolved around a proposal to remove trade barriers to their free flow, which, if successful, would have led to higher demand and unsustainable resource management, ${ }^{152}$ rather than conservation—as advocated by environmentalists.

149 Since 1975, the number of protected species has been constantly growing, as new species are included at nearly each meeting of the Conference of the Parties (COP).

150 Convention on International Trade in Endangered Species of Fauna and Flora, Mar. 3, 1973, 993 U.N.T.S. 243 [hereinafter CITES], Art. II.

$15^{1} \mathrm{WT} / \mathrm{CTE} / \mathrm{M} / 58$, para. 1.34. Cites, Art. ViII(1)(b).

$15^{2}$ See Robert Housman and Durwood Zaelke, 'Trade, Environment, and Sustainable Development: A Primer' (1992) 15 Hastings International \& Comparative Law Review 532,562 . 
The possibility to adopt trade measures to protect endangered species of any kind was highly controversial, as suggested by the reaction of several Southeast Asian governments and their allies in the developing world towards an Austrian law that prescribed 'ecolabelling' for imported tropical timber and timber products. Another example is provided by the US-Taiwan saga under the Pelly Amendment. In that context, the US sanction, which had led Taiwan to take critical steps towards halting commercial trade in tigers and rhinos before it was lifted, was not allowed by GATT rules, and the only refuge for countries wanting to adopt similar measures would have been engaging in an uphill, and most likely unsuccessful, battle under Article xx. Trade liberalization was the overarching rule and the protection of fauna and flora, or the environment more broadly, clearly just an exception.

\section{II}

The NAFTA drafters, mindful of the possibility that the parties might introduce measures in compliance with ciTEs rules, and that these measures might restrict trade between them and violate one or more of the core rules of the agreement, introduced a reference to the Convention in Article 104, clarifying that "in the event of any inconsistency between [NAFTA] and the specific trade obligations set out [in the Convention] such obligations shall prevail to the extent of the inconsistency, provided that where a Party has a choice among equally effective and reasonably available means of complying with such obligations, the Party chooses the alternative that is the least inconsistent with the other provisions of this Agreement."153

Although it did not really address the underlying problems, as inconsistencies were not likely to occur between NAFTA and CITEs, but rather between NAFTA and a domestic measure adopted within the framework provided by CITES, this provision does acknowledge that the goals pursued by CiTES, among other environmental treaties, are valuable and the willingness to try and mediate between the sometimes-conflicting objectives of trade and environmental instruments. On the other hand, however, it still reflects the distinction between 'trade issues', dealt with in the text of NAFTA, and 'nontrade issues' — such as the protection of the environment—dealt with in other agreements outside of the realm of trade law, and the hierarchy that ensues. ${ }^{154}$

153 North American Free Trade Agreement, US-Can.-Mex, Dec. 17, 1992, 32 I.L.M. 289 (1993) [hereinafter NAFTA], Art. 104.

154 As a matter of fact, NAFTA Article 104 specifies that "where a Party has a choice among equally effective and reasonably available means of complying with such obligations, the Party chooses the alternative that is the least inconsistent with the other provisions of this Agreement." 
III

The trade agreement between the United States and Peru, in its Annex 18.3.4 (Forest Annex), instead, requires both parties to suspend the right to export a specific timber-product in case a law, regulation, or other measure regulating its harvest and trade has been violated, ${ }^{155}$ and to establish "an annual export quota for bigleaf mahogany, covering logs, sawn wood, veneer sheets and plywood, at a level and in a manner consistent with Article IV of CITEs." ${ }^{156}$ For the first time, the protection of certain species of plants became the rule in the text of a trade agreement, and not just in that of a multilateral environmental treaty. The Annex to the PTPA actually reproduces and further elaborates on certain rules of a multilateral environmental treaty, placing them on equal footing with trade rules, covered by the same general dispute settlement mechanism, and legitimizing trade sanctions for environmental purposes. As explained by the US representative at the CTE, the agreement was supposed to be a tool precisely to assist Peru to combat illegal logging and associated trade and to promote trade in legal wood products. ${ }^{157}$

The concept of 'greening' trade rules seems to have acquired a whole new meaning. These agreements, and others belonging to this 'new' generation, do not ignore environmental concerns, nor they simply 'accommodate' them. Rather, they actively promote the protection and preservation of the environment.

Another example is provided by the International Convention for the Conservation of Atlantic Tunas (ICCAT). One of the Recommendations of the Commission established by the Convention requires the parties to adopt the measures necessary "to prohibit landings from fishing vessels, placing in cages for farming and/or the transshipment within their jurisdiction of tunas or tuna-like species caught by IUU fishing activities." Once again, a potentially trade-restricting rule we once could only find in an environmental instrument can now also be found in a trade agreement. According to Article 24.21 of USMCA, for instance, "in support of international efforts to combat IUU fishing and to help deter trade in products from IUU fishing," each party shall adopt, maintain, review, or revise measures to "address the transshipment at sea of fish caught through IUU fishing or fish products derived from IUU fishing."

\footnotetext{
155 PTPA Forest Annex, Art. 3.c.ii.

156 Ibid., Art. 3.f.

$157 \mathrm{WT} / \mathrm{CTE} / \mathrm{M} / 57$ (Sept. 30, 2014), para. 1.27.

158 ICCAT Recommendation to Adopt Additional Measures Against Illegal, Unreported and Unregulated Fishing (June 19, 2004). USMCA, Art. 24.21(2)(b)(ii).
} 
The examples provided in the previous paragraphs are evidence of the adoption of approaches previously held 'in contempt' by the trade community with regards to the environment. The introduction of environmental exemptions, for instance, stands in contrast with the idea that non-discrimination represents the rule and countries' freedom to protect the environment should be pigeonholed in narrow exceptions to avoid the risk that they might be used to introduce economic protection and lead to abuse. Even the decision of the Appellate Body to rely on external non-WTO sources to interpret GATT provisions represents an approach that would have been deemed unacceptable a few decades before, as panels were supposed to only rely on GATT law. The drafting of new rules prohibiting certain types of subsidies not only-and primarily-because trade-distorting but, most importantly, because environmentally harmful, marks a stark departure from the motives that had inspired the negotiations on subsidies during the first years of the GATT/WTO, where government subsidies were disciplined "as part of the broader quest for free trade." 159

These new approaches, it is argued in this book, are the result of a gradual change in the perception of the trade/environment nexus, which largely originated in the environmental community and was facilitated by its increasing interactions with the trade community. The progress made since the 1970s, is considerable. For many years, the trade policy elite, "deploying traditional conceptual frameworks" had played "the role of gatekeeper of policy ideas, monopolizing not only the production but also the legitimation and authorization of acceptable policy proposals." ${ }^{160}$ While members of the environmental community demanded incessantly to be heard, their protests stopped at the doors of the WTO, and the lack of support from developing countries, among other factors, contributed to maintaining the wall between the trade and environmental community.

159 Gary Clyde Hufbauer, 'Subsidies', in Jeffrey J. Schott (ed.), Completing the Uruguay Round (Institute for International Econimcs, 199o), p. 93. As aptly explained by Hufbauer, without such disciplines, "each nation will be reluctant to lower its own trade barriers. Indeed, it can be argued that the elimination of tariffs and quotas, without comparable discipline on subsidies and other behind-the-border barriers, will simply promote the growth of these opaquer forms of protection." Ibid.

16o Andrew Lang, 'The Role of the Human Rights Movement in Trade Policy-Making: Human Rights as a Trigger for Policy Learning' (2007) 5 New Zealand Journal of Public International Law 77, go. 
Although, during those first years, environmentalists were not successful in forming a united front and standing up to free-traders and ended up playing by free-trade rules, rather than creating their own, ${ }^{161}$ they gradually began to question the underlying principles and norms of the trading system, and to frame them in a new light. Rather than focusing only on the impact of trade on growth and resource allocation, the environmental community has given voice to a different set of preoccupations and have provided impetus for an alternative discourse. ${ }^{162}$ For instance, environmentalists have stimulated collective thinking and knowledge production about the impact of trade and trade instruments on the different components of the global environment, as well as on the potential use that can be made of trade instruments for environmental protection. ${ }^{163}$ By starting these new kinds of discourses, the environmental community has planted the seeds of new ideas, acknowledging the instrumental role of trade liberalization and the positive relation with environmental protection. Once the trade policy elite ceased to be an impregnable fortress, these new ideas could begin to grow and further develop. This process, it is argued, has been facilitated by two series of factors: first, progress in the degree of interaction between the trade and environmental communities and, second, an increasing convergence of the environment and development agendas.

\subsection{From Weak to Strong Integration}

The creation of the СтE in 1994 marked the end of the clinical isolation in which the trade and environmental communities had coexisted for many years, at least at the international level. At first, however, the integration between the two communities within the CTE, and the WTO more broadly-i.e. in other committees where issues at the intersection between trade and environment were treated - was more nominal than real. ${ }^{164}$ International relation scholars

161 See e.g. the approach adopted during the 1987 negotiations on the Montreal Protocol for the Protection of the Ozone Layer, or the fact that environmentalists have, for many years, framed the debate as 'trade and', just like the trade community has.

162 As explained by Finnemore and Sikkink, this act of calling attention to certain issues or even 'creating' issues through a process of reinterpretation or renaming is generally referred to by social movement theorists as 'framing'. See Martha Finnemore and Kathryn Sikkink, 'International Norm Dynamics and Political Change' (1998) 52(4) International Organization 887,897 . Andrew Lang describes in these terms the approach towards the trade/human rights nexus. Lang, 'The Role of the Human Rights Movement' (n 16o).

163 See e.g. some of the opinions expressed at the GATT Symposium on Trade, Environment and Sustainable Development on July 28, 1994.

164 As an example, the СвD (observer at the СтЕ), has not been granted such status at the TRIPS Council, despite the continuous requests and despite dealing with overlapping issues, such as access to genetic resources and benefits sharing. In a March 2011 meeting, 
refer to this type of integration as 'weak integration' or as 'low institutional capacity for reciprocal learning, which occurs when, among other things, communities' actors have unequal access to each other's discussions, linkages are based on informal arrangements, and relations are predominantly hierarchical. ${ }^{165}$ In fact, during the first years of the CTE's existence, only a handful of environmental international organizations had been granted observer status, ${ }^{166}$ the criteria for being granted such status were unclear, and their role within the Committee was mostly limited to an 'act of presence': as a representative described it, "you give them a flag. They come to the meetings and they sit there. That is it."167

As years went by, the number of 'environmental' observers grew, including most MEA s Secretariats, which had been initially excluded. ${ }^{168}$ Moreover, their role slowly became substantially more active, first simply presenting on certain topics and later intervening in the debates, next to Member states representatives. ${ }^{169}$ The interactions between the СтE and environmental organizations have become more formalized and frequent, the relationship between the two communities and the interests they represent less hierarchical, the two communities have gained a more equal access to each other's discussions,

the Members gathered in the TRIPS Council could not even agree on whether to invite the Свр Secretariat to give a briefing on the Nagoya Protocol right after it was adopted. See IP/C/M/65 (May 10, 2011).

165 Melissa Gabler, 'Norms, Institutions and Social Learning: An Explanation for Weak Policy Integration in the WTo's Committee on Trade and Environment' (2010) 10(2) Global Environmental Politics 8o, 91.

166 The organizations having observer status since the beginning were: the UN, UNCTAD, the International Monetary Fund (IMF), UNEP, the United Nations Development Program (UNDP), the Commission on Sustainable Development (CSD), FAO, the International Trade Centre (ITC), the Organization for Economic Cooperation and Development (OECD), and EFTA. See WT/CTE/M/1 (Mar. 6, 1995).

167 Gabler, 'Norms, Institutions and Social Learning' (n 165) 107.

168 The first two MEA s Secretariats to be granted observer status at the CTE were CITES and the United Nations Framework Convention on Climate Change (UNFCCC) in 1997. As of today, the other MEAs Secretariats that have been granted such status are the CBD and ICCAT.

169 For the first 14 meetings of the СтЕ, observer environmental organizations did not have any active role. In 1997, for the first time, "in order to deepen the CTE's understanding of the linkages between the multilateral environment and trade agendas," the Secretariats of several MEAs were invited to make presentations and prepare background papers for the discussions. WT/CTE/M/14 (June 26, 1997) and WT/CTE/M/15 (Nov. 20, 1997). In 200o, the CтE began organizing 'MEA s Information Sessions', which have been planned several times after that and have been an important forum to discuss several issues at the intersection between trade and the environment. WT/CTE/M/24 (Sept. 19, 2000). 
and they have become more open in their deliberations. In other words, the integration has become stronger and the institutional capacity for reciprocal learning higher.

The presence of the environmental community in discussions on issues at the intersection between trade and the environment-a presence that has become stronger, more formalized, and on an equal footing - has the power to influence policy outcomes and deliberations. ${ }^{170}$ The discussions in the СтE, for instance, have been evolving, as environmental voices have become more frequent. A main concern that was constantly raised at nearly every single meeting over the first years of the Committee was that the wTO was not an environmental protection agency and the role of the CTE should be limited to trade-related issues and it should in no way engage "in adopting rules specifically aimed at protecting the environment."171 As a result, discussions under Item 1 of the Agenda dealt with the compatibility of trade measures in MEA S with the Wто, assuming the WTO legal framework adequately accommodated environmental concerns: as it appears from the record of a СTE meeting in 1995, "environmental measures with significant trade effects must be compatible with the open, equitable and non-discriminatory nature of the multilateral trading system, which meant that these measures must conform to its fundamental provisions"172 and Article XX was sufficient to address any concern of the environmental community. In the early years, even when certain members began to argue that it was necessary to better "reconcile the need to accommodate the legitimate goal of environmental protection ... with the need to preserve the open, equitable and non-discriminatory character of the wTо,"173 they would do that by proposing amendments to the existing exception clause, thus reflecting a clear hierarchy between trade and non-trade issues. And cross-community interactions tended to be similarly hierarchical, with the representatives from environmental organizations being very marginally involved in the discussion, compared to their involvement today.

As years went by, the presence and role of members of the environmental community became more significant and new issues came to be introduced in

170 The CTE is not here considered as a homogeneous block, but rather as a forum where representatives from Member states of the wTO meet to discuss matters at the intersection between the environment and trade. It is however argued that these representatives belong to the larger trade community and are seldom exposed to the discussions occurring in environmental fora, unless appropriate communication channels are established.

$171 \mathrm{WT} / \mathrm{CTE} / \mathrm{M} / 21$ (July 26, 1999), para. 39. See also wто, Trade and the Environment at the WTO (2004).

$172 \mathrm{WT} / \mathrm{CTE} / \mathrm{M} / 4$ (Oct. 10. 1995), para. 8.

173 Ibid. 
the discussions - such as logging, environmental labelling, fisheries subsidies, and environmental goods and services. Although some Members initially questioned the competence of the Committee or the wT more broadly to address some of these issues, ${ }^{174}$ they slowly gained ground and began featuring in all the more recent meetings. Two of these even began topics of negotiations. ${ }^{175}$

One should not forget that institutional integration occurred, first and foremost, at the domestic level, where it played a crucial role not only in the context of domestic and bilateral discussions but in influencing international politics as well. In regional and bilateral trade negotiations, the cooperation between representatives of the trade and environmental communities has become more formal and, in certain cases, mandatory. While during the final phases of the NAFTA negotiations, environmental experts were involved on an ad-hoc basis, in 1994 the Trade and Environment Policy Advisory Committee was created, and the 2002 revision of the US Trade Act required its involvement in the negotiations of trade agreements, making its report-as those of the other committees involved - a mandatory requirement before the country could enter into any trade negotiations. To the same effect, preventive environmental reviews have now become mandatory, after Clinton's Executive Order 13,141. As a result, those countries that have experienced a stronger integration of environmental and trade voices within their territory have been able to bring 'greener' proposals to the negotiating table. Moreover, their representatives have brought their heightened state of awareness to the СтE or other WTO bodies, influencing, brick by brick, multilateral discussions as well.

\subsection{Watching the Seeds Grow}

For the longest time, many viewed the WTO architecture on subsidies as static, as not capable of change. But civil society soon came to knock on our doors, drawing our attention to the perilous state of much of the world's fish stock. Its message was clear, the wто has

174 See e.g. WT/CTE/M/35 (Nov. 19, 2003), para. 16 [regarding illegal logging]; WT/CTE/M36 (May 19, 2004), para. 18 [regarding environmental labelling].

175 See supra Section 2.1 for an analysis of the current fisheries subsidies' negotiations. The other issue that has become object of negotiations is that of the liberalization of environmental goods and services (EGS). The discussions on this topic started to be conducted regularly within the Сте and its Special Sessions after Doha, which envisaged it as one of the Committee's task (Article 31(iii)). These discussions created a perfect breeding ground for the current plurilateral negotiations on an Environmental Goods Agreement. In 2014, 14 Wто Members, in the margins of the World Economic Forum in Davos, started negotiations on an Environmental Goods Initiative and were later joined by four more Members. 
a vital role to play in protecting the world's fish stock, in saving it from depletion. ${ }^{176}$

PASCAL LAMY, WTO Public Forum 2007

The fisheries subsidies negotiations provide a great example of the way in which the interactions between the trade and environmental community have grown and become more open, dense, and formal over time. In this context, environmental organizations have played a crucial role in their contribution to advancing the discussions on this issue, in particular over the course of the first years, both within the CTE and later in the NGR. Several information sessions were held with UNEP and the CBD Secretariat, precisely to facilitate the CTE Members' understanding of the issues, ${ }^{177}$ and work done on the topic by international organizations such as UNEP and FAO was reviewed carefully by the CTE Secretariat and used as a basis for discussions. ${ }^{178}$ In 2007, UNEP and the World Wide Fund (wwF) prepared a document entitled Sustainability Criteria for Fisheries Subsidies: Options for the WTO and Beyond, which was supposed to provide technical input to the negotiations. ${ }^{179}$ The two organizations emphasized the importance of setting certain minimum criteria - in the areas of fish stock, fishing capacity, and fisheries management - to eliminate the negative impacts of subsidies on fisheries conservation. In fact, the criteria set out in the UNEP/WWF document, which reflected the requirements under current international fisheries instruments for responsible fisheries, ${ }^{180}$ were used by WTO negotiators when drafting the new regulations. In the study, for instance, overcapacity is recognized as a critical problem and as "the most important link between subsidies and overfishing,"181 and capacity-enhancing subsidies to any fishery that is not substantially under-capacity are presented as inherently very risky. ${ }^{182}$ As a result, most of the textual proposals submitted by wTO Members to the NGR have included capacity-enhancing subsidies among the

\footnotetext{
176 Pascal Lamy, Address at the 2007 WTO Public Forum: Civil Society is Influencing the wTO Agenda, Oct. 4, 2007.

$177 \mathrm{WT} / \mathrm{CTE} / \mathrm{W} / 187$ and $\mathrm{WT} / \mathrm{CTE} / \mathrm{W} / 149$.

178 WT/CTE/W/167 and WT/CTE/W/167/Add.1.

179 David K. Schorr and John F. Caddy, 'Sustainability Criteria for Fisheries Subsidies: Options for the WTO and Beyond' (2007) UNEP/WWF Working Paper. See WT/CTE/M/45, para. 17.

180 These international instruments include the United Nations Convention on the Law of the Sea (UNCLOS), the Code of Conduct for Responsible Fisheries, and the Fish Stocks Agreement.

181 Schorr and Caddy, 'Sustainability Criteria for Fisheries Subsidies' (n 179) 15.

182 Ibid.
} 
list of prohibited subsidies, and so does the most recent text presented by the Chair. ${ }^{183}$

Outside of the specific case of fisheries subsidies negotiations, where the cooperation between environmental and trade officials has directly affected the outcome of the negotiations, representatives of the environmental community have stimulated collective thinking about the trade/environment nexus from an environmental standpoint, rather than merely a trade-centered one, as well as knowledge production about the potential use that can be made of trade instruments for environmental protection. In a 2011 meeting of the CTE, for instance, the Secretary-General of the 2012 United Nations Conference on Sustainable Development discussed the notion of 'green economy', 184 and stated that he hoped the international community, including the стE, "would consider how the international trading system could assist countries that choose to embark on a green economy path."185 Only a few months later, the representative from UNEP briefed the Committee on the 'green-economy potential' of different economic sectors and emphasized the role of international trade in transitioning to a green economy. ${ }^{186}$ Those were the very first times that the notion of 'green economy' was introduced in the Committee. ${ }^{187}$ Until then, the concept was well known in environmental circles, but not necessarily among trade officials or among the national delegates sitting in the CTE: as rightly emphasized by Pauwelyn, "delegates representing a state in the WTO context are mostly not the same as those representing the same state in UNEP." 188

Since then, the 'green economy', in all its different components, has become a permanent feature of nearly all subsequent CTE meetings. Representatives of several countries have been sharing their own experience with green economy initiatives and tracked their progress year after year, at times agreeing

183 See TN/RL/GEN/181/Rev.1 (EU), proposed Article 1.1(a); TN/RL/GEN/189/Rev.1 (Indonesia) proposed Article 2.1(a); TN/RL/GEN/192 (ACP Group) proposed Article 2.1(c); TN/RL/ Gen/187/Rev.2 (Argentina, Colombia, Costa Rica, Panama, Peru, Uruguay) proposed Article 2.1.3(a); TN/RL/GEN/193 (LDC Group) proposed Article 2.1(d)-(e). The exceptions are the proposal from New Zealand, Iceland, Pakistan and the one from Norway. See also TN/RL/W/274/Rev. 6, Art.3.7.

$184 \mathrm{WT} / \mathrm{CTE} / \mathrm{M} / 5^{2}$ (Sept. 6, 2011), paras. 97-111.

185 Ibid., para. 106.

$186 \mathrm{WT} / \mathrm{CTE} / \mathrm{M} / 53$ (Jan. 27, 2012), para. 19. See also UnEP, Towards a Green Economy (n 38).

187 The first time was actually during the meeting which took place on November 9, 2010. WT/CTE/M/51 (May 31, 2011).

188 Joost Pauwelyn, Conflict of Norms in Public International Law (Cambridge University Press, 2003), p. 15. 
to cooperate in the context of specific projects. During a 2013 meeting, for instance, Mr. Alberto Parenti, representing the European Union, presented on the Single Market for Green Products (SMGP) initiative, adopted as a Commission communication and recommendation on April 9, 2013, aimed at addressing the proliferation of green labels and methods to prove green credentials by levelling the playing field for green producers. ${ }^{189}$ During the course of the very same meeting, the representative from Switzerland, to support the implementation of environmental schemes as a way to increase sustainable trade, expressed interest in participating in the pilot phase of the European SMGP initiative. ${ }^{190}$ At the same time, he presented Switzerland's own project, the so-called Green Economy Action Plan, which spurred significant interest in a number of countries, in particular developing ones. In fact, not only developed but less-developed countries as well have been briefing the CTE on their own initiatives. 191

In a handful of years, the notion of green economy had become something to be discussed by both the environmental and trade community, as well as something they could even discuss together. In the context of one of the most recent Wто Public Forums, for instance, the 'green economy' was at the center of most discussions, involving both trade and environment specialists. Significantly, during a meeting of the Committee in March 2019, the WTO Secretariat briefed the members on the outcome of the Forum explaining that:

The discussions had emphasized the need for ever closer and positive links between open, rules-based and inclusive trade on the one hand, and a healthy environment on the other. The role that trade and the што could play in supporting the achievement of environmental goals was also considered. Trade could serve as a tool to disseminate and scale up environmentally sound technologies, and to accelerate the transition to a green economy. More green investment was needed in developing countries, not least to improve access to energy and sanitation. ${ }^{192}$

The increasing openness of the trade elite and the increasing interactions with the environmental community have allowed the spreading of environmental

\footnotetext{
189 Commission Communication on Building the Single Market for Green Products, Apr. 9, 2013, Сом(2013)196 Final. WT/CTE/M/55 (Aug. 16, 2013), paras. 1.28-1.30.

190 Ibid., para. 1.58 .

191 See e.g. Thailand's Product Carbon Footprint Program or Costa Rica's Carbon Neutrality Program (Ibid., paras. 1.56-57).

192 WT/CTE/M/66 (Mar. 22, 2019), para. 2.15.
} 
concepts and notions: while there was a time when the two communities spoke different languages - when the word 'protection' warmed the heart of environmentalists and sent chills down the spine of free traders-now they have started to understand each other and the trade community has begun to use certain environmental terms and concepts on a daily basis. These interactions have facilitated the production of new knowledge regarding how certain aspects of the trading system operate.

Another instrument that has proven very useful in this regard is the carrying out of environmental impact assessments, which, it has been argued, can contribute to providing 'feedback loops', by monitoring the outcomes of policy choices, in this case, the impact of trade agreements on the environment. ${ }^{193}$ According to organizational theorists, this feedback function can provide the impetus for policy-makers to learn - that is to rethink the "beliefs which these policy-makers hold concerning how the trading system operates, and what the outcomes of their interventions are likely to be."194

The idea that trade can be a powerful tool to promote sustainable development and environmental protection is now largely shared by the trade community and is not simply a possibility environmentalists discuss in their circles. And the negotiations on fisheries subsidies, the new environmental provisions in FTA s, and the European strategy towards a sustainable development future are all signals that the knowledge that has been produced thanks to these interactions can indeed impact the actions of policy-makers, helping them to reformulate their strategies and their policy preferences.

\subsection{The Development Factor}

Normative changes towards a system that envisions trade and trade norms as a powerful tool to promote sustainable development and environmental protection largely depend on the internal dynamics of each country, as well as on the relative power in the international arena of countries that are more or less supportive of 'green' agendas.

As the previous chapters have shown, at least two lessons can be learned from the unfolding of the trade/environment story. First, that it is not exclusively a 'trade and environment' story, but rather a story that, to capture the evolution of the relationship between the two regimes in its entirety, takes into account the development agenda as well, and the role it played in said

\footnotetext{
193 See e.g. Bo Hedberg, 'How Organizations Learn and Unlearn', in Paul C. Nystrom and William H. Starbuck (eds.), Handbook of Organizational Design (Oxford University Press, 1981).

194 Lang, 'The Role of the Human Rights Movement' (n 16o) 97.
} 
evolution. Second, that it is not just an 'international' story. How the environment is perceived within each country vis-à-vis its development and economic needs contributes greatly to the position each country adopts in both regional and international fora and, indirectly, to the concrete development of the nexus.

The latter has evolved towards what the author has defined promotionbased model at a greater speed in certain regional contexts than at the level of WTO rules and decisions. This discrepancy should not come as a surprise. It is precisely the need to constantly balance environmental and developmental considerations that can explain, at least in part, the difficulties encountered by the members of the environmental community in pushing their agenda through and in being able to spread new ideas and produce new knowledge within multilateral trade institutions.

With the development agenda gaining ground both in environmental and trade fora, the principle of sustainable development becoming the overarching principle guiding future negotiations, and the principle of common but differentiated responsibilities (CBDR) a fundamental component underlying them, addressing the role of trade as a meaningful means to achieve environmental goals in the context of multilateral negotiations became increasingly difficult. ${ }^{195}$

Previous chapters in this book have already provided several examples of these difficulties. In the context of the СтE, as the members of the Committee started preparing its first Report to be issued in 1996, representatives from developed countries were the ones who were proposing more integrated solutions, recognizing that existing WTO provisions did not have adequate scope to accommodate MEA s' trade related environmental measures (TREMS). The strongest positions suggested an ex ante MEA accommodation through a formal amendment or collective interpretation of Article Xx. ${ }^{196}$ On the other side

195 Many MEA s contain a caveat such as the one we can find in the chapeau of GATT Article xx. See e.g. United Nations Framework Convention on Climate Change, May 9, 1992, 1771 U.N.T.S. 107, 31 I.L.M. 849, Article 3.5. See Chapter 4, note 38.

196 See wTo, Committee on Trade and Environment (CTE), Non-Paper by the European Communities on Item 1, Feb. 19, 1996; CтE 1996 Report, para. 169. The EU and EFTA countries, had advanced this proposal years before within the EMIT Group. See GATT, GATT Council Meeting, 6 February, C/M/247; GATT, Standing Group on Environmental Measures and International Trade (EMIT Group), The GATT and the Trade Provisions of MEAS. Submission from the EC, TRE/W/5, 1992; Report of the Meeting Held on 19 November 1992. Note by the Secretariat, TRE /8, 1992; Report of the Meeting Held on 4-5 February 1993. Note by the Secretariat, TRE/9, 1993; Report of the Meeting Held on 5-6 October 1993. Note by the Secretariat, TRE/13, 1993. Other developed countries settled for proposals arguing for more moderate reforms. See CTE, Non-Paper. Submission by Switzerland on Item 1, 
of the barricade, the vast majority of developing and least-developed countries (and only a handful of developed ones) strenuously opposed to all these suggestions, presenting counterproposals that were far more compatible with GATT philosophy and did not require elaborate changes to the existing trade legal framework. ${ }^{197}$ Ultimately, this latter position had the best, with the Chair tabling a draft that fit well with the existing wTо frame. ${ }^{198}$

The position of developing countries vis-à-vis the introduction of trade/ environment discussions within the WTо was made particularly clear at the dawn of the Doha Round. As well summarized by Steinberg, "developing countries wanted to exclude environment, labor, investment, and competition policy and include their issues." ${ }^{199}$ Developing and least-developed countries' concerns are also partly to blame for the delay in concluding a WTO agreement on fisheries, especially given the issues raised by those countries "that have low income and poorly resourced fishers, achievement of these goals will depend in most part on the fisheries sector and with the removal of subsidies, the consequences can be catastrophic." 200

As explained by Biermann, "concerns over green protectionism limit the willingness of many wто members to integrate environmental considerations further into trade agreements." ${ }^{201}$ For discussions to move forward, rules and

May 20, 1996; The Relationship between the Provisions of the MTs and Trade Measures for Environmental Purposes, including those Pursuant to MEAs-Submission by New Zealand, $\mathrm{WT} / \mathrm{CTE} / \mathrm{W} / 2 \mathrm{O}$.

197 In particular, see eмiт Group, Report of the Meeting Held on 5-7 July 1993. Note by the Secretariat, TRE/12, 1993, and CTE. Non-Paper Submission by India on Items 1 and 5 (July 23, 1996).

198 During the several discussions on this topic, several developed country representatives slightly modified their proposals to meet developing countries' concerns. See, for instance, the evolution of proposals submitted by the EU. See CTE, Non-Paper by the European Communities on Item 1 (Feb. 19, 1996).

199 Richard H. Steinberg, 'In the Shadow of Law or Power? Consensus-Based Bargaining and Outcomes in the GATT/WTO' (2002) 56(2) International Organization 339, 353.

200 Radika Kumar et al, "The Effectiveness of Fisheries Subsidies as a Trade Policy Tool to Achieving Sustainable Development Goals at the wTo' (2019) 100 Marine Policy 132.

201 Frank Biermann, 'The Rising Tide of Green Unilateralism in World Trade Law: Options for Reconciling the Emerging North-South Conflict' (2001) 35(3) Journal of World Trade 421, as quoted in Rachel McCormick, 'A Qualitative Analysis of the wTo's Role on Trade and Environment Issues' (2006) 6(1) Global Environmental Politcs 102, 108. As noted by McCormick, several barriers exist "to developing-country support for the resolution of trade and environment issues: inherent mistrust of developed-country use of traderelated environmental measures, lack of perceived benefits available to developing countries, overstatement of resultant limitations on market access to developing country products, and limited understanding of and capacity to negotiate on many trade and environment issues." 109 . 
institutions need to evolve in ways that are equally acceptable and beneficial to the environmental community and to developing countries.

\subsection{It's Not All about the Environment}

So, let's redouble our efforts to continue this work. Let's build a more inclusive trading system, which supports the SDG s, keeps pace with the evolving nature of trade, and which paves the way for a better world.

Roberto AZEvêdo, WTo Public Forum, October 2, 2018

Development has indeed become an essential part of the equation and it is no longer all about the environment. If it is true that the principle of sustainable development, by replacing 'economic growth' pure and simple as the ultimate goal to be pursued with trade rules, procedures, and institutions, has brought significant changes to the international trade regime, a similar paradigm shift has affected the environmental regime. In fact, both elements-development and sustainability — have contributed to shifting the debate "from traditional environmentalism with its primary focus on environmental protection, to the notion of sustainability, which requires a much more complex process of trading off social, economic, and environmental priorities." 202

As already discussed at length, while, during the 1972 Stockholm Conference, the environment was center stage in the international domain and Maurice Strong had to organize the famous Founex meeting to convince developing countries to take part in the Conference, as years went by, these countries found a stronger voice and by the time the Brundtland Report was being drafted, environment and development had become inseparably linked in the international agenda. In Rio, 20 years after Stockholm, instead of The Human Environment, the focus was on Environment and Development. The environment found itself forced to step aside and share the stage with development: they had become "co-stars in a new show - the international agenda for sustainable development."203

According to the 2030 Agenda, the Sustainable Development Goals to be pursued by 2030 include:

202 Neil Carter, The Politics of the Environment: Ideas, Activism, Policy (Cambridge University Press, 2018), p. 215.

203 Ibid. See United Nations Conference on Environment and Development, Rio de Janeiro, Brazil, June 3-14, 1992, Rio Declaration on Environment and Development, U.N. Doc. A/ CONF.151/26/Rev.1 (Vol. I), Annex I (Aug. 12, 1992) [hereinafter Rio Declaration], Principles 5,6 , and 7 . 
to end poverty and hunger everywhere; to combat inequalities within and among countries; to build peaceful, just and inclusive societies; to protect human rights and promote gender equality and the empowerment of women and girls; and to ensure the lasting protection of the planet and its natural resources. We resolve also to create conditions for sustainable, inclusive and sustained economic growth, shared prosperity and decent work for all, taking into account different levels of national development and capacities. ${ }^{204}$

It follows that, while environmental protection is certainly an important component of sustainable development and is given an important place within the 2030 Agenda, it also needs to be balanced and integrated with all the other components and goals. Over the years, a major challenge has in particular been posed by the need to balance and integrate environmental protection with development. The overarching goal of the 2030 Agenda is to eradicate "poverty in all its forms and dimensions, including extreme poverty," 205 and all the other goals are envisioned as stepping stones towards it. Underlying all these goals is the acknowledgment that developing and least-developed countries face particular difficulties in this process and the enunciation of the principle of common but differentiated responsibilities. ${ }^{206}$

As a consequence, the majority of targets related to the environmental goals of the 2030 Agenda reflect the CBDR principle and integrate the need to take into account the conditions of less-developed countries and support them in the attempt to achieve these goals at their very core. Here are some relevant examples:

13.a Implement the commitment undertaken by developed-country parties to the United Nations Framework Convention on Climate Change to a goal of mobilizing jointly $\$ 100$ billion annually by 2020 from all sources to address the needs of developing countries in the context of meaningful mitigation actions and transparency on implementation and fully

\footnotetext{
2042030 Agenda, para. 3.

2052030 Agenda, Preamble.

2062030 Agenda, para. 12, which refers to Principle 7 of the Rio Declaration: "States shall co-operate in a spirit of global partnership to conserve, protect and restore the health and integrity of the Earth's ecosystem. In view of the different contributions to global environmental degradation, States have common but differentiated responsibilities. The developed countries acknowledge the responsibility that they bear in the international pursuit of sustainable development in view of the pressures their societies place on the global environment and of the technologies and financial resources they command."
} 
operationalize the Green Climate Fund through its capitalization as soon as possible. ${ }^{207}$

14.a Increase scientific knowledge, develop research capacity and transfer marine technology, taking into account the Intergovernmental Oceanographic Commission Criteria and Guidelines on the Transfer of Marine Technology, in order to improve ocean health and to enhance the contribution of marine biodiversity to the development of developing countries, in particular small island developing States and least developed countries. ${ }^{208}$

15.b Mobilize significant resources from all sources and at all levels to finance sustainable forest management and provide adequate incentives to developing countries to advance such management, including for conservation and reforestation. ${ }^{209}$

The need to take into account the interests and needs of less-developed countries should characterize all means to implement environmental goals, including trade. If, on the one hand, the 2030 Agenda contains a specific mention of "unilateral economic, financial, or trade measures" countries might decide to pursue one or more of the 17 goals set out therein, on the other hand, it adds an important caveat:

States are strongly urged to refrain from promulgating and applying any unilateral economic, financial or trade measures not in accordance with international law and the Charter of the United Nations that impede the full achievement of economic and social development, particularly in developing countries. ${ }^{210}$

As a result, trade can be framed as a means to pursue environmental protection goals only as long as the other components of sustainable development are not undermined.

2072030 Agenda. Goal 13 refers to the need to "take urgent action to combat climate change and its impacts."

208 Ibid. Goal 14 refers to the conservation and sustainable use of "the oceans, seas and marine resources for sustainable development."

209 Ibid. Goal 15 refers to the need to "protect, restore and promote sustainable use of terrestrial ecosystems, sustainably manage forests, combat desertification, and halt and reverse land degradation and halt biodiversity loss."

210 Ibid., para. 30. 
This caveat is significantly different from the one that was included in the Rio Declaration, which was first penned by the GATT drafters in the chapeau of Article $\mathrm{xx}$, and which reflects the more traditional neoliberal narrative. Under this model, the limits within which countries were allowed to adopt trade-related measures to protect the environment were dictated by the trade community — as mentioned earlier, it was the trade community, relying on the prevailing neoliberal narrative, who determined what constituted the rule and what the exception, as well as the requirements of that exception.

Principle 12 of the Rio Declaration, after declaring that "States should cooperate to promote a supportive and open international economic system that would lead to economic growth and sustainable development in all countries, to better address the problems of environmental degradation," significantly added:

Trade policy measures for environmental purposes should not constitute a means of arbitrary or unjustifiable discrimination or a disguised restriction on international trade ... Unilateral actions to deal with environmental challenges outside the jurisdiction of the importing country should be avoided. $^{211}$

Principle 16 further clarified that "national authorities should endeavor to promote the internalization of environmental costs and the use of economic instruments ... without distorting international trade and investment." 212 The language used in these two Rio principles was clearly inspired by the chapeau of Article XX of the GATT- "subject to the requirement that such measures are not applied in a manner which would constitute a means of arbitrary or unjustifiable discrimination ... or a disguised restriction on international trade."213 As explained in chapter 3 , the chapeau had been added to the original formulation of Article xx to avoid the adoption of domestic measures that would constitute (unnecessary) barriers to trade and would (unduly) burden commerce.

The language used in the 2030 Agenda is different from the one we find in Principles 12 and 16 of the Rio Declaration. In this new context, the only limit to the adoption of "unilateral economic, financial, or trade measures" to pursue any of the Goals enshrined in the Agenda is the respect of the development needs of less-developed countries. ${ }^{214}$ No mention is made with regards

\footnotetext{
211 Rio Declaration, Principle 12.

212 Ibid., Principle 16.

213 GATT, Article Xx, Chapeau.

214 To be precise, this limit was already envisioned in the Action Plan agreed on in Stockholm. In that context, however, reference was also made to the need for these measures not to
} 
to the disturbance of trade flows and international commerce. This caveat, however, does pose certain limits to the use of trade instruments to protect the environment-or achieve any other sustainable development goals. As a matter of fact, the Agenda defines the Goals and Targets as "integrated and indivisible," 215 meaning that each of them should be pursued without prejudice to the attainment of the others.

\subsection{Two Birds with One Stone}

The mainstreaming of the notion of green economy as a fundamental component of sustainable development has led to a gradual convergence of the environmental and development agendas. Going 'green' has accordingly become a necessary step to development, requalifying the whole idea of environmental protection in the eyes of the strenuous promoters of the development agenda. In other words, discussions have been moving forward when development was factored in the equation. The fisheries subsidies issue can once again be used as a helpful example. Since the very beginning, in the context of the debates on whether and how to modify trade rules to prohibit certain types of fisheries subsidies harmful for the environment, both within the trade and environmental communities, a lot of weight has been given to the special needs of less-developed countries and in particular of vulnerable coastal states. The importance of these special needs was already acknowledged in the 1999 Communication from Iceland to the General Council in preparation for the Seattle Ministerial Conference. ${ }^{216}$ Since then, all proposals from developed countries have always emphasized the need to account for developing and least-developed countries concerns in any future draft of the agreement. ${ }^{217}$

Since the adoption of the Chair text in 2007, the negotiations have been characterized by an equal attention to the environmental benefits that can be obtained with a revised ASCM discipline and to the need to safeguard and protect the needs of less-developed members, providing an excellent example of

hamper trade. Recommendation 103 recommended that Governments would take the necessary steps to ensure, on the one hand, that "where environmental concerns lead to restrictions on trade, or to stricter environmental standards with negative effects on exports, particularly from developing countries, appropriate measures for compensation should be worked out," and on the other, that "all States participating in the Conference agree not to invoke environmental concerns as a pretext for discriminatory trade policies or for reduced access to markets." Stockholm Action Plan.

2152030 Agenda, Preamble.

$216 \mathrm{WT} / \mathrm{GC} / \mathrm{W} / 229$.

217 See e.g., WT/CTE/W/105, paras. 32-9; WT/CTE/W/51, paras. 18(e) and 20; TN/RL/GEN/186 (proposed Article 1.4); and TN/RL/GEN/181/Rev.1 (proposed Article 4.1). 
the 'integrated and indivisible' nature of the sustainable development goals and targets. And once the Chair text was concluded, both environmentalists and less-developed wто members welcomed it with enthusiasm: WWF released a statement calling the draft "a serious and constructive text" and "a solid basis for negotiations to proceed," while the African, Caribbean, and Pacific Group of States (ACP), small and vulnerable economies, and Pacific Island members likewise echoed support for the Chair's treatment of S\&D treatment. ${ }^{218}$ As a matter of fact, developing and least-developed countries had been deeply involved in the discussions since the very beginning. ${ }^{219}$

Environmental organizations as well, working on the subject, have paid particular attention to this aspect. In July 2005, for instance, a representative from UNEP briefed the CTE on the result of a recent Roundtable on Promoting Development and Sustainability in Fisheries Subsidies Disciplines, which addressed different options to advance the sustainable development of artisanal fisheries while disciplining subsidies and investigating how special and differential treatment in the context of fisheries subsidies could link new trade rules to development, poverty reduction and environmental issues. ${ }^{220}$ Ten years later, FAO, UNEP and UNCTAD submitted a joint statement on fisheries subsidies, aiming to move forward the trade-related targets under the SDG s and signing onto a roadmap to end harmful fisheries subsidies, ${ }^{221}$ and 91 countries, four intergovernmental organizations, and 15 civil society groups signed on to this global roadmap to eliminate damaging subsidies by 2020.222 In the statement, the three organizations have identified certain minimum outcomes that would contribute to the members' efforts to meet Target 14.6,

218 International Centre for Trade and Sustainable Development, 'Fisheries Subsidies Text Provides a Good Starting Point, Delegates Say', 7(22) Bridges Trade BioRes (Dec. 18, 2007). The S\&D treatment foreseen in the more recent text of the proposed amendment to the ASCM include transition periods where certain provisions do not apply to LDC s and the complete exclusion of LDC s from the articles on prohibited subsidies, with the exception of the prohibition of subsidies to IUU fishing and in overfished conditions. TN/RL/W/ 274/REv.6, proposed Article 5.

219 See e.g., submissions from China (TN/RL/w/88), Brazil (TN/RL/W/176), and Antigua and Barbuda, Belize, Fuji Islands, Guyana, the Maldives, Papua New Guinea, Solomon Islands, St. Kitts and Nevis (TN/RL/W/136).

220 WT/CTE/M/4O (Sept. 2, 2005) and WT/CTE/GEN/2O (July 13, 2005). See UnEP, Reflecting Sustainable Development and Special and Differential Treatment for Developing Countries in the Context of New WTO Fisheries Subsidies Rules (2005).

221 UNCTAD-FAO-Une P, Joint Statement: Regulating Fisheries Subsidies Must Be an Integral Part of the Implementation of 2030 Sustainable Development Agenda (2016) [hereinafter UNCTAD-FAO-UNEP Joint Statement].

$\mathrm{WT} / \mathrm{CTE} / \mathrm{M} / 63$, para. 1.63 . 
which include the "clear prohibition of subsidies that contribute to overfishing and overcapacity, including subsidies linked to IUU fishing, and those that undermine sustainable development," and special attention and treatment to be given to "developing countries, in particular, the least developed ones and Small Islands Developing States (SIDS), so that they can continue to use their marine resources sustainably." 223 And as a result, most siDs signed on to the joint statement. ${ }^{224}$

In other words, as long as appropriate and effective special and differential treatment is an integral part of the negotiations, developing and leastdeveloped countries have proven to be eager to participate in the discussions on reforming ASCM rules to prohibit those fisheries subsidies which might harm the sustainability of marine resources. It was precisely some of these countries-Indonesia, the least-developed countries (LDC) Group, and the ACP Group, to be specific - that proposed the exclusion from the overall discipline those fisheries subsidies that do produce a positive environmental impact. And those were the same countries that in 1972 had to be 'convinced' to send a representative to Stockholm.

The free trade agreements signed by the United States with Chile and Peru offer another example of the integration of development and environmental concerns within the same instrument. Since the adoption of the Lacey Act, which prohibits trade in wood products manufactured from illegally harvested and traded timber, the United States had tried to combat illegal logging and trade and promote trade in legal wood products, and recently the country has been pursuing this goals through free trade agreements. ${ }^{225}$ In addition, these agreements offer an opportunity to, simultaneously, engage in capacity building. ${ }^{226}$ In the Annex on Environmental Cooperation of the US-Chile FTA, for instance, the two countries committed to work together to build capacity to improve wildlife protection and management, among other things. ${ }^{227}$ Because

223 UNCTAD-FAO-UNEP Joint Statement.

224 Antigua and Barbuda, Bahamas, Barbados, Cuba, Dominica, Dominican Republic, Fiji, Grenada, Guinea-Bissau, Guyana, Haiti, Jamaica, Kiribati, Marshall Islands, Mauritius, Micronesia, Nauru, Palau, Papua New Guinea, Samoa, Sao Tome and Principe, Seychelles, St. Kitts and Nevis, St. Lucia, St. Vincent and the Grenadines, Suriname, Timor-Leste, Trinidad and Tobago, Tong, Tuvalu, Vanuatu, all part of the ACP group.

225 Lacey Act, 16 U.S.C. $\$ \S 3371-3378$. WT/CTE/M/57, para. 1.27.

$226 \mathrm{WT} / \mathrm{CTE} / \mathrm{M} / 57$, para. 1.27.

227 US-Chile FTA, Annex 19.3, Art. 1(g). Other areas of cooperation include developing a pollutant release and transfer register in Chile, reducing mining pollution, improving environmental enforcement and compliance assurance, sharing private sector expertise, improving agricultural practices, reducing methyl bromide emissions, and increasing the use of cleaner fuels. 
of the Annex, the parties even established a Joint Commission, which contributed greatly to strengthening and improving Chile's laws. And forests protection is just one of the many areas where this cooperation has benefitted Chile's environmental legal framework, others including energy efficiency and conservation and environmental law enforcement more broadly. As a result, many US Government agencies, such as the EPA, the National Science Foundation, and the National Park Service, are actively engaged in Chile, carrying out the objectives set out in the FTA Annex.

When the FTA was being negotiated, Chile - just like other countries the US signed similar agreements with-lacked the resources necessary to improve the environmental legal framework. These improvements might of course have occurred without the cooperation with the United States but "without the 'external' impulse given by the negotiation of this kind of provision, these changes may not have occurred, or would have occurred at a later stage."228 For the very same reason, several initiatives have been established within the СтE to provide developing and least-developed countries with the assistance they need to be able to improve their environmental legal and institutional framework. ${ }^{229}$ And even when discussing national initiatives, industrialized countries make sure to explain how these initiatives would impact less-developed country members and to what extent they foresee S\&D treatment. ${ }^{230}$

A final example of a topic negotiated within the wTO-and already addressed in one $\mathrm{FTA}^{231}$ — which is aimed at protecting the environment while advancing the development agenda is the Joint Statement on Fossil Fuel Subsidy Reform (FFSR), signed by 16 countries during the 1th wTO Ministerial Conference. In the statement, the signatories "confirmed their intention to seek the rationalization and phase out of inefficient fossil fuel subsidies that encouraged wasteful consumption, while recognizing that reform should take into account the specific needs and conditions of developing countries and

\footnotetext{
228 oECD, Environment and Regional Trade Agreements (2007), 48.

229 WT/CTE/M/43 (Feb. 12, 2007), Annex 1; WT/CTE/M/45 (Jan. 9, 2008), Annex 1; WT/CTE/ M/46 (Jan. 12, 2009), Annex 1. WT/CTE/M/47 (Aug. 31, 2009), paras. 59-66; WT/CTE/M/48 (Jan. 12, 2010), Annex 1; WT/CTE/M/54 (Mar. 15, 2013), paras. 2.1-2.3.

230 In a 2013 meeting, for instance, the representative of Switzerland "explained that the needs of developing countries were being taken into account in the implementation of the Green Economy Action Plan through sector policies, as well as development and economic cooperation, bilateral experience exchanges and initiatives." WT/CTE/C/56 (Jan. 31, 2014), para. 1.42.

231 EU-Sing. FTA, Art. 13.11(3).
} 
to minimize the possible adverse impacts on their development in a way that protected poor and affected communities."232

The negotiations on liberalizing environmental goods can, on the other hand, be used as a counterexample. Begun in 2014, and involving 18 WTO members, it has been argued that it was precisely the lack of support of developing countries that contributed to the stall of the negotiations. ${ }^{233}$ Two of the lists of environmental goods used in the context of the negotiations-the Asia-Pacific Economic Cooperation (APEC) list and the wTO list-mostly contained industrial products, representative of the interests of developed countries, as opposed to the list comprising 108 so-called environmentally preferable products (EPP), which would have better reflected developing countries' interests. ${ }^{234}$

\subsection{Missed Opportunities}

Changes in ideas have led, as this book has argued, to an evolution in the rules and procedures of the international trade regime. This evolution has unveiled, removing one layer after another, the instrumental role of trade liberalization in protecting the environment and promoting sustainable development. As long as the trading system is anchored to traditional neoliberal ideas, however, it will remain impossible for the synergetic nature of the relationship between the trade and environmental regimes to fully come to life. As such, several areas are still 'lagging behind', the most emblematic probably being the determination of 'likeness' and the treatment of process and production methods (PPM S) under international trade law. ${ }^{235}$

The non-discrimination norm, which constitutes the cornerstone of the international trade regime, is translated into rules-most-favored nation and national treatment—which prohibit countries from discriminating between

\footnotetext{
232 WT/CTE/M66 (Mar. 22, 2019).

233 See Jaime de Melo and Jean-Marc Solleder, 'Barriers to Trade in Environmental Goods: How Important They are and What Should Developing Countries Expect from their Removal' (2018) FERDI Working Paper No. 235.

234 Ibid.

235 See generally on PPM s, Christiane R. Conrad, Processes and Production Methods (PPMS) in WTo Law: Interfacing Trade and Social Goals (Cambridge University Press, 2011). See also Steven Charnovitz, 'The Law of Environmental 'PPMs' in the wTO: Debunking the Myth of Illegality' (2002) 27 Yale Journal of International Law 59. Jason Potts, 'The Legality of P PMs Under the GATT' (2008) IISD 23; David Sifonios and Andreas Ziegler, “"Tuna-Dolphin Forever"? The Development of the PPм Debate Related to Trade and Environment in the WTO' (2020) 12 Indian Journal of International Economic Law 106.
} 
and among 'like' products. According to the characterization of 'likeness' given by the Working Group on Border Tax Adjustment (втA) in $1970^{236}$ and further developed by the Appellate Body, ${ }^{237}$ four elements should be taken into account to determine whether two products are 'like':

(i) the physical properties of products; (ii) the extent to which the products are capable of serving the same or similar end-uses; (iii) the extent to which consumers perceive and treat the products as alternative means of performing particular functions in order to satisfy a particular want or demand; and (iv) the international classification of the products for tariff purposes. ${ }^{238}$

In Japan-Alcoholic Beverages II, the Appellate Body stated that the focus of the 'likeness' determination was on the BTA criteria, while no proof of trade effects was required. ${ }^{239}$ As years went by, the determination of 'likeness' has gradually become, as explained by the Appellate Body in EC-Asbestos, "a determination about the nature and extent of a competitive relationship between and among products." ${ }^{240}$ As argued by Trachtman, by focusing the 'likeness' determination solely on competitive relationship,

the Appellate Body has diminished 'like products' from its ordinary meaning in an important way, because it has excluded national governmental

236 Report by the Working Group on Border Tax Adjustment, L/3464 (November 20, 1970).

237 Pierre M. Dupuy and Jorge E. Viñuales eds., Harnessing Foreign Investment to Protect the Environment (Cambridge University Press, 2013), p. 484.

238 Appellate Body Report, European Communities-Measures Affecting Asbestos and Products Containing Asbestos, WT/Ds135/AB/R (Mar. 12, 2001) [hereinafter EC_Asbestos], para. 101. It was the Appellate Body in Japan-Alcoholic Beverages II that added the fourth criterion-international tariff classification - to the three already set by the Working Group on Border Tax Adjustment. See Appellate Body Report, Japan-Taxes on Alcoholic Beverages, WT/DS8/AB/R (Nov. 1, 1996) [hereinafter Japan-Alcoholic Beverages II], 21-2.

239 Appellate Body Report, Japan-Alcoholic Beverages II, at 16-23. With this pronouncement, the Appellate Body rejected the argument that judges consider 'aims and effects' in the context of discrimination cases. See Robert E. Hudec, 'GATT/WTO Constraints on National Regulation: Requiem for an "Aim and Effects" Test' (1998) 32 International Law 619, 62o. See also Joel P. Trachtman, 'WTO Trade and Environment Jurisprudence: Avoiding Environmental Catastrophe' (2017) 58(2) Harvard Journal of International Law 273, 278.

240 Appellate Body Report, EC-Asbestos, para. 99. See Trachtman, 'wTo Trade and Environment Jurisprudence' (n 239) 277. After its decision in Philippines—Distilled Spirits, the Appellate Body has extended this determination of 'likeness' beyond para. 4 of Article III. See Appellate Body Report, Philippines - Taxes on Distilled Spirits, WT/DS403/AB/R (Dec. 21, 2011). 
determinations of regulatory categories from consideration in connection with the determination of likeness. The result is that when two products are sufficiently in competition, they are determined to be like products even if they differ in exactly the dimension that gives rise to the regulatory concern. ${ }^{241}$

This interpretation of 'likeness' has obvious consequences for the trade/ environment nexus. Let us consider two scenarios, one where a government decides to adopt a domestic environmental regulation to address consumption externalities (i.e. based on how much a product pollutes), and a second one where the environmental regulation is aimed at addressing production externalities (i.e. based on the environmental impact of the process used to manufacture the product).

In the first scenario, according to the interpretation of 'likeness' outlined above, the products would most likely be found to be 'like', unless consumers are affected to the point that competition is altered. However, considering that consumers are generally victims of information asymmetries compared to producers and are by definition indifferent when it comes to externalities, ${ }^{242}$ this outcome would appear to be extremely rare. In EC-Asbestos, after the panel found that chrysotile asbestos fibers and fibers that can be substituted for them were 'like' products under Article III:4 of the GATT, the Appellate Body reversed this finding arguing instead that the two products were not 'like' because the different composition of the two products had important health implications. ${ }^{243}$ Notwithstanding its importance, this pronouncement is not particularly helpful from an environmental perspective for two reasons. First, the Appellate Body considered health risks in its 'likeness' determination insofar as they affected competitiveness. ${ }^{244}$ Second, the health risks were considered as part of the existing criteria (physical properties) ${ }^{245}$ and asbestos fibers do affect the physical properties of a product (product-related PPM), while from an environmental perspective, the way in which a product is produced, despite being an essential component of the product itself, often leaves no detectable traces in the final product (non-product-related PPM). It is

241 Trachtman, 'wTo Trade and Environment Jurisprudence' (n 239) 277-8.

242 Ibid., 278. Frieder Roessler, "The Scope of Regulatory Autonomy of wTo Members under Article III:4 of the GATT: A Critical Analysis of the Jurisprudence of the wTo Appellate Body' (2015) Robert Schuman Center for Advanced Studies Policy Paper 3.

243 Appellate Body Report, EC — Asbestos, para. 113.

244 Ibid., para. 114.

245 Ibid., para. 113. 
therefore likely that an environmental regulation that addresses consumption externalities would be found in violation of Article III:4. The only possibility for the Member adopting the regulation would be to try and justify it under GATT Article Xx.

In the context of regulations that address production externalities, the outcome does not seem to be much different. In Tuna/Dolphin, the panel had argued that these kinds of regulations, because thy regulate processes rather than products, could not fall under Article III:4 of the GATT, but the strict scrutiny of Article XI would apply instead. ${ }^{246}$ Although, after the establishment of the wTO, the Appellate Body did not have the opportunity to pronounce itself on the applicability of Article III:4 to regulations of processes, even if this provision applied, the determination of 'likeness' outlined above, as linked to the competitive relationship of the products, would make it very unlikely for two products with different non-product related PPMs to be found 'not like.'247 In the recent US-Tuna II (Mexico) dispute, the Appellate Body did acknowledge that "it is permissible in theory under the national treatment obligation to differentiate among products on the basis of how they have been produced. ${ }^{248}$ However, this pronouncement was made in reference to the TBт Agreement (and in particular Article 2.1), which includes certain PPMs explicitly under its scope, ${ }^{249}$ and the possibility to extend this reasoning to the national treatment obligation under GATT is questionable. Once again, the one viable solution is to attempt a justification of the regulation via GATT Article XX.

What this analysis shows is that, in either scenario, the WTO does not prohibit countries from adopting environmental regulations to address either consumption or production externalities and to differentiate products based

246 Report of the GATT Panel, United States—Restrictions on Imports of Tuna, DS21/R-39S/155 (Sept. 3, 1991) (not adopted), 155 .

247 This outcome would be possible once again in case consumers differentiated between the products to the point that competition could be considered altered. Trachtman, 'WTO Trade and Environment Jurisprudence' (n 239) 283.

248 Appellate Body Report, United States-Measures Concerning the Importation, Marketing and Sale of Tuna and Tuna Products, WT/DS381/ABR (May 16, 2012) [hereinafter US-Tuna II (Mexico)], para. 211. See also Trachtman, 'WTO Trade and Environment Jurisprudence' (n 239) 282.

249 The Appellate Body found that "Article 2.1 should not be read ... to mean that any distinctions, in particular ones that are based exclusively on particular product characteristics or on particular processes and production methods, would per se constitute 'less favourable treatment' within the meaning of Article 2.1." Appellate Body Report, USTuna II (Mexico), para. 211. See Trachtman, 'WTo Trade and Environment Jurisprudence' (n 239) 283 . 
on their process and production methods, ${ }^{250}$ but their 'legality' is dependent on passing the 'Article XX-test'. In other words, the wTO does allow P PM-based measures, but only as long as they are eligible under an exception clause. ${ }^{251}$ As explained by Charnovitz, "whenever it violates GATT Articles I, III, or XI, a PPM will be reviewed under GATT Article Xx(b) or (g) and the chapeau to the Article." 252

This approach, where trade liberalization remains the rule and environmental protection merely the exception, relies heavily on the neoliberal narrative, firm in depicting PPM $\mathrm{s}$ - and in particular those that are non-product related - as a slippery slope, as allowing Member states to discriminate products on these grounds would risk setting off a protectionist tide and disrupting international trade. ${ }^{253}$ This approach shows a strong reluctance in introducing environmental differentiation in a wTO rule, ${ }^{254}$ motivated by the fear that "if a nation is allowed to use the process characteristic as the basis for trade restrictive measures, then the result would be to open a Pandora's box of problems that could open large loopholes in the GATT."255 However, excluding PPM $\mathrm{s}$

250 See e.g. the pronouncement of the Appellate Body in US —Shrimps: "We have not decided that the protection and preservation of the environment is of no significance to the Members of the WTo. Clearly, it is. We have not decided that the sovereign nations that are Members of the WTO cannot adopt effective measures to protect endangered species, such as sea turtles. Clearly, they can and should. And we have not decided that sovereign states should not act together bilaterally, plurilaterally or multilaterally, either within the што or in other international fora, to protect endangered species or to otherwise protect the environment. Clearly, they should and do." Appellate Body Report, US-Shrimps wT / DS58/AB/R (Oct. 12, 1998), para. 185 (emphasis in original).

251 See Charnovitz, 'The Law of Environmental 'PPMs' in the wTO' (n 235) 59. Potts, 'The Legality of PPMs' (n 235) 23.

252 Charnovitz, 'The Law of Environmental 'PPMs' in the WTO' (n 235) 11.

253 Robert Housman, 'The North American Free Trade Agreement's Lessons for Reconciling Trade and the Environment' (1994) 30 Stanford Journal of International Law 379, 407;Jagdish Bhagwati, 'On Thinking Clearly About the Linkage Between Trade and the Environment' (2000) 5 Environment \& Development Economics 483, 491, and 'Afterword: The Question of Linkage' (2002) 96(1) American Journal of International Law 126, 133.

254 The GATT's reluctance to take into account PPM s reflects one of the underlying differences between the trade and environmental communities: the former concerned only with products and the latter with processes. But see how environmental differentiation has been addressed in recent investment disputes. See Parkerings v. Lithuania, Award, para. 392.

255 John H. Jackson, 'World Trade Rules and Environmental Policies: Congruence or Conflict?' (1992) 49 Washington \& Lee Law Review 1227, 1243. The same fear has been surrounding the possibility to rely on the exception provided in GATT Article XXI as well (national security). However, surprisingly to many, a wTo panel in the recent Russia-Transit case, has indeed opened the Pandora's box, by ruling that "WTO panels have jurisdiction to review aspects of a Member's invocation of Article xxi(b)(iii), that Russia had met the 
from the 'likeness' analysis proves to be problematic in the context of environmental measures as, more often than not, their environmental footprint is not reflected in the composition of a product, just like a can of tuna does not tell us whether that tuna was caught with nets that injured dolphins, a bag of shrimps does not tell us whether they came from a country that requires turtle excluder devices, and electricity does not tell us whether it is sourced from renewables.

By describing the evolution undergone by the relationship between the international trade and environmental regimes, this book has emphasized the discrepancy between its true nature, evidenced by the recent developments described in this book, and the prevailing neoliberal narrative of the trading system, which fails to fully capture a system which is increasingly working for the protection of the environment and the promotion of sustainable development goals. However, the approach towards the determination of 'likeness' and the treatment of PPM s under WTO law, or even the discussions over the applicability of Article Xx to the ASCM, can be read as a signal that, although rules and procedures have begun to change, the norms and principles of the trading system, and the underlying narrative, have not. In other words, the conditions that have made the evolution of the trade/environment nexus possible have run aground at the first, shallower level of learning: new provisions have been introduced, but the pillars on which the prevailing normative narrative rests are yet to be shaken.

This narrative, however - just like any narrative — is not eternal: "over time, other stories have been told about trade's purpose, producing different policies and encouraging different politics" 256 and the time may be ripe to tell a new story. It may be time to rethink the overarching purpose of the liberal trade project and of the trading system, precisely in light of the evolution described here.

requirements for invoking Article $\mathrm{XXI}(\mathrm{b})(\mathrm{iii})$ in relation to the measures at issue, and therefore, that the transit bans and restrictions were covered by Article XxI(b)(iii) of the GATT 1994." The panel continued stating that "Unlike evaluations of whether measures are covered by the exceptions in Article XX, an evaluation of measures under Article XXI(b)(iii) does not necessitate a prior determination that the measures would be wTO-inconsistent had they been taken in 'normal times' (para. 7.108). The Panel therefore considered that, "once it had found that the measures at issue were within its terms of reference and that Ukraine had established their existence, the 'most logical next step' was to determine whether the measures were covered by Article XxI(b)(iii)" (para. 7.109) (emphasis added). Panel Report, Russia-Measures Concerning Traffic in Transit, WT/DS512/R (Apr. $5,2019)$.

256 Harlan Grant Cohen, 'What is International Trade Law For?' (2019) 113(2) American Journal of International Law 326, 327. 